\title{
Pediatric Lung Transplantation
}

\author{
Stuart C Sweet MD PhD
}

\author{
Introduction \\ Indications and Contraindications to Transplantation \\ Candidate Evaluation and Pre-Transplant Management \\ Donor Evaluation \\ Transplant Surgical Procedure \\ Post-Transplant Management \\ Immunosuppressive Regimen \\ Antimicrobial Regimen \\ Rehabilitation \\ Monitoring \\ Outcomes and Risk Factors \\ Survival \\ Causes of Death \\ Adolescence \\ Complications \\ Immediate Post-Transplant Phase \\ Early Phase \\ Late Phase \\ Summary
}

\begin{abstract}
Pediatric lung transplant is a viable option for treatment of end-stage lung disease in children, with $>100$ pediatric lung transplants reported to the Registry of the International Society of Heart and Lung Transplantation each year. Long-term success is limited by availability of donor organs, debilitation as a result of chronic disease, impaired mucus clearance resulting from both surgical and pharmacologic interventions, increased risk for infection resulting from immunosuppression, and most importantly late complications, such as chronic lung allograft dysfunction. Opportunities for investigation and innovation remain in all of these domains: (1) Ex vivo lung perfusion is a promising technology with the potential for increasing the lung donor pool, (2) evolving extracorporeal support strategies coupled with effective rehabilitation will effectively bridge critically ill patients to transplant, and most importantly, (3) research efforts intended to increase our understanding of the underlying mechanisms of chronic lung allograft dysfunction will ultimately lead to the development of effective therapies to prevent or treat the variety of chronic lung allograft dysfunction presentations. Key words: lung transplantation; organ donation; cystic fibrosis; pulmonary hypertension. [Respir Care 2017;62(6):776-798. () 2017 Daedalus Enterprises]
\end{abstract}

\section{Introduction}

It has been more than 50 years since the first human lung transplant was performed by Hardy. ${ }^{1}$ But it was not until the early 1980s that the combination of calcineurin inhibitors and improved surgical techniques allowed for acceptable survival for lung and heart-lung transplant recipients. $^{2,3}$ The first reports of lung transplant in children were published in the early $1990 \mathrm{~s},{ }^{4-6}$ with registries reporting a steady increase in the number of children receiving lung transplants through the 1990s. From 1986 through June 2013, 2,091 lung and 689 heart-lung transplants in children were reported to the Registry for the International Society for Heart and Lung Transplantation (ISHLT). ${ }^{7}$ Following a steady increase in pediatric lung transplants in the first decade of this millennium, with 125 reported to 


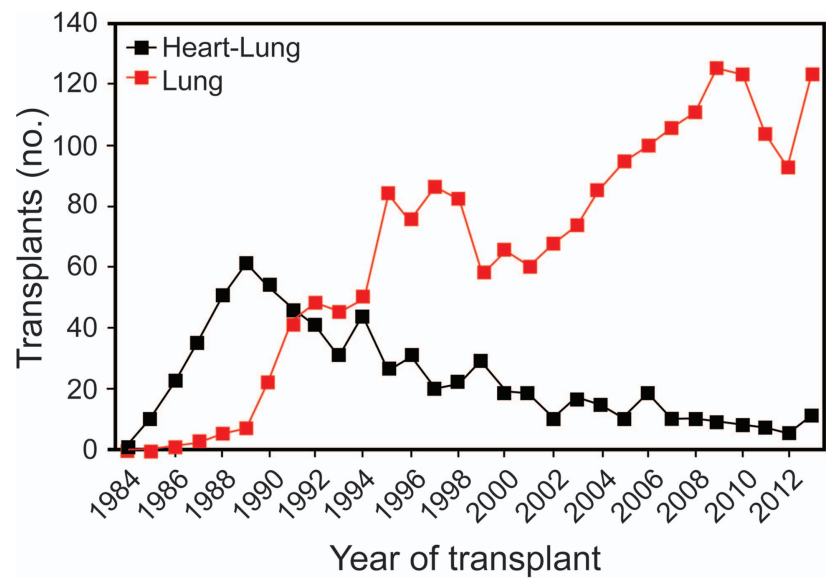

Fig. 1. Yearly number of pediatric lung and heart-lung transplants reported to the International Society for Heart and Lung Transplant registry 1984-2014. Data from Reference 7.

the ISHLT registry in 2009, numbers have remained stable since then (Fig. 1). ${ }^{7}$ This review will outline indications, key outcomes and complications, and therapeutic challenges facing pediatric lung transplant candidates and recipients, highlighting areas where effective respiratory therapy and rehabilitation are important.

Most children with end-stage lung disease receive a bilateral lung transplant. Although more common in the early experience, heart-lung transplant is now generally reserved for patients with left-ventricular failure or congenital heart disease not amenable to repair. Roughly 10 heart-lung transplants/y are now reported to the ISHLT registry. ${ }^{7}$ So-called "domino" procedures with a healthy native recipient heart transplanted into a second recipient are now exceedingly rare (Fig. 1). Lung transplant is performed in children much less frequently than heart, liver, and kidney transplants. The reason for this is multifactorial, including lower prevalence of end-stage lung disease in children and improved survival in cystic fibrosis (CF) and pulmonary hypertension..$^{8,9}$ Perhaps not surprisingly,

Dr Sweet is affiliated with the Division of Allergy, Immunology and Pulmonary Medicine, Department of Pediatrics, Washington University School of Medicine, St Louis, Missouri.

Dr Sweet presented a version of this manuscript at the 55th RESPIRATORY CARE Journal Conference, "Pediatric Respiratory Care," held June 10-11, 2016, in St Petersburg, Florida.

Dr Sweet discloses relationships with the National Institutes of Health, Genentech, and Optum Health.

Correspondence: Stuart C Sweet MD PhD, Washington University, One Children's Place, Campus Box 8116, St Louis, MO 63110. E-mail: sweet@kids.wustl.edu.

DOI: $10.4187 /$ respcare.05304

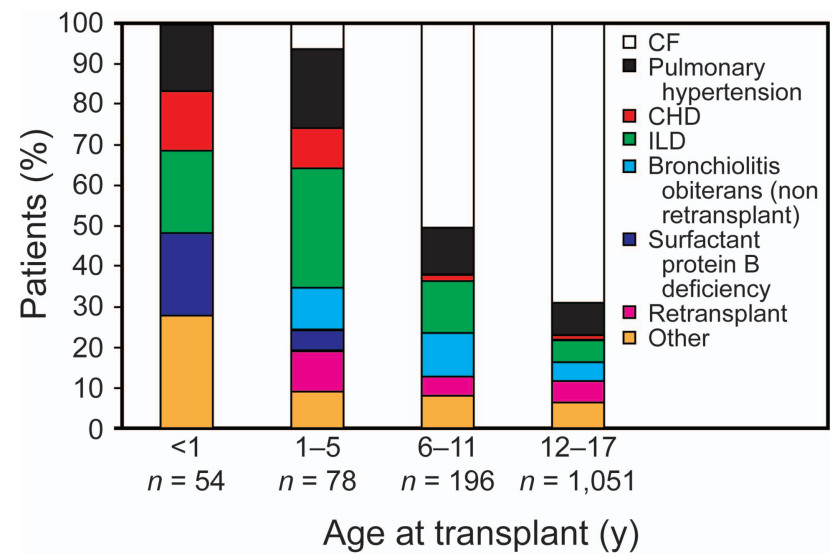

Fig. 2. Distribution of pediatric lung transplants reported to the International Society for Heart and Lung Transplant registry by age and indication January 2000 to June 2014. CF = cystic fibrosis, $\mathrm{CHD}=$ congenital heart disease, ILD = interstitial lung disease. Data from Reference 7.

pediatric lung transplant is a low-volume service in most centers. Among roughly 40 centers reporting pediatric lung transplants, nearly $90 \%$ of centers perform $<5$ transplants/y. Nearly half of pediatric lung transplants are performed in a small subset of centers. ${ }^{7}$ In the United States, despite allocation policy changes intended to increase allocation to children, compared with adolescents and adults, the mortality rate for pediatric candidates remains higher than for most adults. ${ }^{10}$ Efforts to increase access to lung transplant for children through additional allocation policy changes and increased utilization of potential donor lungs remain important. ${ }^{11}$

\section{Indications and Contraindications to Transplantation}

Lung transplantation is indicated in children with untreatable end-stage lung disease or pulmonary vascular disease. Initially, the majority of children receiving lung transplants had CF. However, indications have become considerably broader with growing experience with the procedure, including transplantation of infants with congenital, end-stage lung disease ${ }^{12,13}$ (Fig. 2). Notably, COPD, emphysema, and idiopathic pulmonary fibrosis (the most common diagnoses leading to lung transplant in adults) are virtually absent from pediatric age groups. Pulmonary hypertension (mostly associated with congenital heart disease) and other pulmonary vascular diseases (primarily pulmonary vein stenosis and rarely alveolar capillary dysplasia); disorders of surfactant metabolism, such as surfactant protein $\mathrm{B}$ and $\mathrm{C}$ deficiencies and ATP-binding cassette A3 (ABCA3) transporter and NKX2.1 mutations; interstitial lung disease; bronchopulmonary dysplasia; and pulmonary hypoplasia make up the diagnoses leading to lung transplant in children younger than $1 \mathrm{y}$ of age. ${ }^{13-16}$ 
children and often higher in infants with severe lung disease who remain hospitalized while awaiting transplant. In addition, patients may also be responsible for relocation costs. Because there are relatively few pediatric lung transplant programs, many patients must move to a different city for an average 3-6-month period (waiting time plus 3 months post-transplant).

In general, patients should be referred for lung transplant early enough so that they would survive long enough to receive organs. In the past, the recommendation was to list patients when anticipated survival without transplant was $<2$ y. The introduction of the Lung Allocation System made this less relevant for adolescents. The Lung Allocation System was developed and implemented in 2005 by the Organ Procurement and Transplantation Network. ${ }^{24}$ Based on models of waiting list mortality and post-transplant survival, the Lung Allocation System prioritizes donor lung allocation to maximize the 1-y transplant survival benefit (Lung Allocation System = post-transplant survival $-2 \times$ waiting list survival, normalized to a $0-100$ scale). Diagnosis, age, height/weight, need for oxygen and ventilator support, pulmonary arterial pressures, 6-min walk distance, and lung function are factors in the model. Implementation of the Lung Allocation System has led to decreases in waiting time and waiting list mortality for adolescents and adults. ${ }^{25}$ The emphasis on waiting list mortality in the algorithm has opened the door for transplant in critically ill patients who previously would not have survived long enough to receive organs, including those requiring mechanical ventilation. Not surprisingly, this group of patients have worse overall survival. ${ }^{26}$ Because allocation of lungs to children $<12 \mathrm{y}$ old remains based on waiting time within 2 urgency tiers, early referral is more important in this population. ${ }^{27}$

Beyond these general principles, referral timing is dependent on underlying disease. Patients with surfactant protein B deficiency, alveolar capillary dysplasia, and significant pulmonary vein stenosis often progress rapidly to refractory respiratory failure requiring extracorporeal membrane oxygenation (ECMO) circulatory support. For this reason, prompt referral and transport to the transport center is prudent once the family understands the need for and agrees to lung transplant evaluation.

Timing is less clear in other disease processes. For example, a series of studies in subjects with CF have led to a general recommendation to proceed with lung transplantation once the $\mathrm{FEV}_{1}$ declines to $<30 \%$ predicted. ${ }^{28-30}$ But even the best of these models can accurately predict mortality $<50 \%$ of the time. ${ }^{29}$ The challenge for timing lung transplant in children with CF was highlighted by Liou et $\mathrm{al}^{31}$ using proportional hazard models developed from the Cystic Fibrosis Foundation and Organ Procurement and Transplantation Network data sets. The authors found that lung transplantation did not provide a survival benefit to children with CF. Their conclusions were tempered by the fact that data were obtained at the time of listing and not at the time of transplant, often 2-3 y before their actual transplant because of waiting time requirements. ${ }^{11}$ In contrast, other studies have demonstrated a survival benefit for children with CF. ${ }^{32,33}$ Because lung transplantation remains the only treatment option available to extend life in patients with CF and end-stage lung disease, most centers evaluate and list patients with $\mathrm{FEV}_{1}$ in the 30s and base the timing of active pursuit of transplant on the clinical picture, including nutritional status, functional status, and frequency of exacerbations. ${ }^{34}$

For patients with idiopathic pulmonary hypertension or pulmonary vascular disease, a cardiac index of $<2 \mathrm{~L} / \mathrm{min} / \mathrm{m}^{2}$, elevated pulmonary vascular resistance, right-atrial pressures of $>7.4 \mathrm{~mm} \mathrm{Hg}$, and right-ventricular end-diastolic pressure of $>10.4 \mathrm{~mm} \mathrm{Hg}$ despite maximal vasodilator therapy predict poor survival. ${ }^{35,36}$ Referral and evaluation are suggested when it is clear that a patient is approaching these limits. Other risk factors that should prompt consideration for transplant evaluation include von Willebrand factor levels of $>240 \%$, elevated uric acid levels, and plasma levels of brain natriuretic peptide $>180 \mathrm{pg} / \mathrm{mL} .^{37-39}$

The decision of whether and when to transplant patients with Eisenmenger syndrome is challenging. Because of the potential for extended survival (some patients can live for years, if not decades, after diagnosis), indication for transplant includes progressive disease (severe hypoxia, syncope, or a limited functional status). In general, lung transplant is the preferred procedure unless the cardiac lesion is not amenable to repair at the time of transplant. ${ }^{40,41}$

Patients with other surfactant-processing disorders, such as surfactant protein $\mathrm{C}$ deficiency, $\mathrm{ABCA} 3$ transporter mutation, or NK2.1x mutation, the presentation and course of disease are variable. ${ }^{42}$ In general, these patients should be referred when they develop progressive respiratory insufficiency unresponsive to medical interventions.

Criteria for transplant evaluation are even less clear in other disease processes. Most pediatric centers consider factors beyond cardiopulmonary function, such as growth and nutrition status, frequency of hospitalizations, and potential for improvement in overall quality of life before deciding when to proceed to lung transplant. Because of this uncertainty, most pediatric lung transplant centers recommend referral well before the patient reaches the tipping point between anticipated waiting list survival and estimated waiting time. ${ }^{17}$

\section{Candidate Evaluation and Pre-Transplant Management}

Lung transplant evaluation is a multi-disciplinary process, including laboratory and radiographic studies as well as consultation with multiple services (Table 2) intended 
Table 2. Recommended Evaluation for Pediatric Lung and HeartLung Candidates

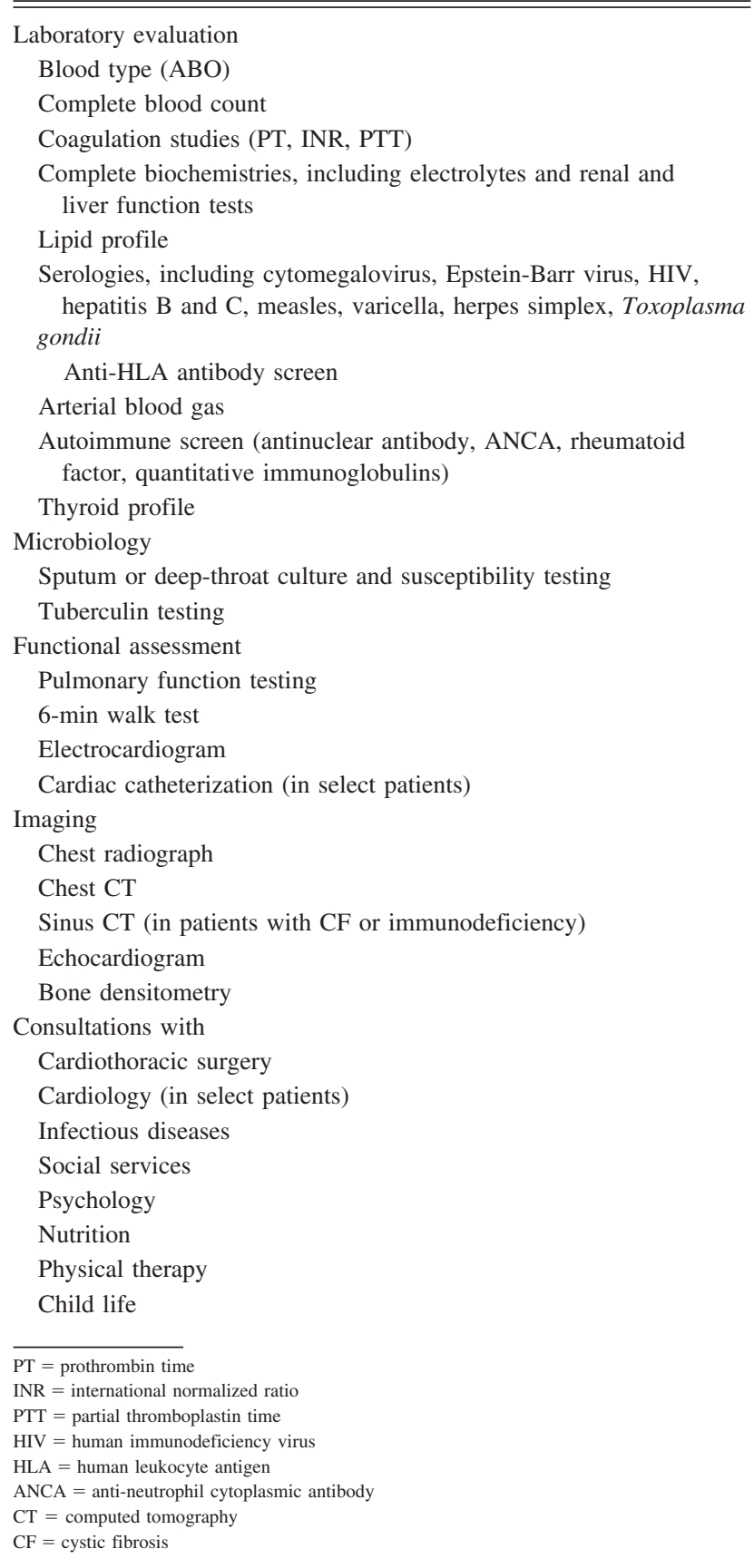

to identify comorbidities that would limit post-transplant survival. Determination of candidacy considers both medical and psychosocial components.

Pre-transplant care is often shared with the referring center with the goal of maximizing the patient's chances of surviving the wait for organs and maximizing the posttransplant outcome potential. Typically, this includes maximizing the nutritional status (including placement of a
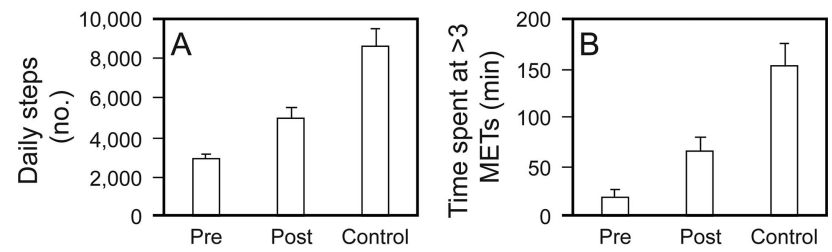

Fig. 3. Patients' participation in daily physical activity before (Pre) and $1 \mathrm{y}$ after (Post) lung transplantation in comparison with healthy age-matched control subjects. A: Daily step count. B: Time spent in activities requiring $>3$ metabolic equivalents (METs). Averages in these groups expressed relative to healthy controls are as follows. A: Pre 34\% and Post 58\%; B: Pre 13\% and Post 44\%. Error bars show standard error. Data from References 46 and 47.

gastrostomy tube if needed), minimizing infectious risks (including ensuring that vaccinations are up to date), and ensuring that the patient and family establish or continue routines for adherence to medical therapies.

Although pulmonary rehabilitation is commonly included in the care of lung transplant candidates and recipients, literature to support its efficacy is scant overall and virtually nonexistent in children. ${ }^{43}$ Several studies in adults have demonstrated that, despite substantial improvements in quality of life over pre-transplant values, patients report persistent limitation of daily physical functioning after transplantation ${ }^{44,45}$ (Fig. 3). These findings are present in patients with improvements in lung function to nearly normal or normal values, suggesting that other factors may be responsible..$^{48}$ Lung transplant candidates are likely to have peripheral muscle dysfunction as a result of inactivity and deconditioning before and during the post-transplant recovery period. ${ }^{49-54}$ Most patients have impairment in nutrition (particularly those with $\mathrm{CF}$ ). The use of corticosteroids before and after transplant may contribute to limb muscle atrophy and myopathy. ${ }^{55,56}$ Finally, calcineurin inhibitors may effect muscle structure and function. ${ }^{57,58}$ Thus, it is reasonable to postulate that pulmonary rehabilitation strategies both before and beginning immediately after transplantation may help to mitigate these effects. ${ }^{59}$

Pre-transplant rehabilitation (Table 3) has been shown to improve exercise capacity and quality of life before transplant. ${ }^{61-63}$ A study of adult subjects demonstrated that each 100-m increase in pre-transplant 6-min walk distance was associated with a 2.6-d decrease in the median length of hospital stay. ${ }^{64}$

Of course, pre-transplant management will vary by disease state. In patients with $\mathrm{CF}$, optimizing airway clearance and managing infection remains a priority. Treatment involves aggressive use of high-frequency chest-wall oscillation devices and/or intermittent percussive ventilation and tailoring of antimicrobial therapy to minimize the infectious burden while avoiding antibiotic resistance. Strategies in patients with pulmonary hypertension and other pulmonary vascular disorders involve maximizing pulmo- 
Table 3. Suggested Elements of Exercise Training During Rehabilitation Before Lung Transplantation

Begin with initial evaluation that examines hemodynamic stability, oxygen requirements, bone health, body mass index, medical comorbidities, respiratory mechanics, and overall functional capacity.

Complete patient assessment using psychological, health-related, and generic (eg, SF-36) quality of life measures, shortness-of-breath questionnaires, manual muscle testing, and 6-min walk distance.

Pulmonary rehabilitation should consist of exercise training, including progressive aerobic exercise and upper/lower extremity strengthening, under close supervision and continuous monitoring.

Exercise should begin at low intensity and be progressed gradually to the highest capacity tolerated by the individual, maintaining adequate oxygenation during activity.

Place strong emphasis on patient/caregiver education, as well as psychological, dietary, and occupational therapy support.

Frequent reassessments are necessary because of the progression of the underlying lung disease; close communication with patients' health-care providers outside of pulmonary rehabilitation is essential.

Data from Reference 60.

nary blood flow. Pulmonary vasodilator therapy, diuretics, anticoagulation, and supplemental oxygen may be of benefit, depending on the underlying disease. Patients with refractory pulmonary hypertension may be candidates for atrial sepstostomy or Pott's shunt procedures. ${ }^{65,66}$ Steroids (either in high monthly dose pulses or daily regimens) and other immunosuppressants may be considered in children with interstitial lung disease. ${ }^{67}$

Most pediatric centers will utilize mechanical ventilation for patients who develop respiratory failure after listing despite the fact that mechanical ventilation is a risk factor for mortality. ${ }^{68}$ Indeed, for infants and toddlers, patient and graft survival were similar for patients requiring mechanical ventilation at the time of transplant. ${ }^{69}$ More recently, extracorporeal support has been used to bridge pediatric and adult patients to transplant, including venovenous ECMO ${ }^{70-72}$ and pumpless, low-resistance membrane oxygenator devices. ${ }^{73}$ Such devices have been used successfully in a child as young as 2 y of age. ${ }^{74}$ Because all extracorporeal support devices carry risks for anticoagulant-related complications, their role in long-term bridging to transplant remains to be clearly defined. Pre-transplant rehabilitation is particularly important in patients with respiratory failure requiring ECMO. Lung transplant outcomes in patients receiving transplant from ECMO were significantly better in patients who were able to ambulate than in those who were not. ${ }^{75,76}$ Therefore, it would not be unreasonable to postulate that rehabilitation will be similarly important when using pumpless devices. Identifying the appropriate use of various forms extracorporeal support and striking the appropriate balance of their therapeutic risks against the benefits of reduced ventilator-induced injury and potential for rehabilitation should provide a fertile opportunity for research.

\section{Donor Evaluation}

For the most part, pediatric lung transplant recipients receive organs from donation after brain death donors. ${ }^{10}$
Evaluation of a potential donor includes arterial blood gases $\left(\mathrm{P}_{\mathrm{O}_{2}} / \mathrm{F}_{\mathrm{IO}_{2}}>300\right.$ preferred $)$, chest radiographs, airway cultures, and airway examination by bronchoscopy. The donor should be free of signs/symptoms of acute viral infection and have negative screens for hepatitis $\mathrm{A}, \mathrm{B}$, and $\mathrm{C}$ and human immunodeficiency virus. ${ }^{77}$ Opportunities to increase the pool of lungs available for transplant have recently become available through techniques that allow ex vivo assessment and therapy of donor lungs (ex vivo lung perfusion). In addition to assessment and conditioning of brain death donor lungs that have failed to meet standard criteria, ex vivo lung perfusion may facilitate increased use of donation after circulatory death donor organs. ${ }^{78}$ Although ex vivo lung perfusion usage is increasing in adult transplant centers, ex vivo lung perfusion technology has yet to be adapted for use with smaller pediatric donors. Given the ongoing shortage of organs, expansion of ex vivo lung perfusion technology into the pediatric space will be another important opportunity for pediatric lung transplant physicians and surgeons.

\section{Transplant Surgical Procedure}

Most procedures in children are performed while they are receiving cardiopulmonary bypass or ECMO. A bilateral anterolateral transsternal "clamshell" incision is made at the fourth intercostal space to optimize visualization and access to both pleural spaces. Recipient pneumonectomies involve first ligating and dividing the pulmonary and arterial and venous vessels and then dissecting out the main bronchus and dividing it with a linear stapling device. The donor lungs typically arrive en bloc with a cuff of the left atrium. They are prepared by dividing and appropriately trimming the left-atrial cuff and main pulmonary artery and trimming each main bronchus to within 2 cartilaginous rings of the upper lobe takeoff. The most common procedure in pediatrics is a bilateral sequential lung transplant with end-to-end rather than telescoping bronchial-tobronchial anastomoses. This approach is felt to minimize 
the potential for stenosis. ${ }^{79,80}$ Pericardial or peribronchial lymphatic tissue from the donor and recipient is used to cover the anastomosis. This approach is intended to improve the blood supply to the vulnerable anastomoses and may also reduce the risk of infection of adjacent vascular structures. ${ }^{79,81}$

Living-donor lobar lung transplant (using a right lower lobe from one donor and a left lower lobe from a second donor) has virtually disappeared in the United States since the introduction of the Lung Allocation System. ${ }^{82}$ Livingdonor lung transplant continues to be utilized in Japan because access to donor organs suitable for children in that country is more difficult. ${ }^{83}$ Other technical variants to allow the use of larger lungs in infants and small children include downsizing the donor organ with a linear stapling device or lobectomy. ${ }^{84}$

\section{Post-Transplant Management}

\section{Immunosuppressive Regimen}

Triple-drug immunosuppression and directed antimicrobial therapy is initiated in the immediate post-transplant period. Immunosuppression typically consists of a calcineurin inhibitor (commonly tacrolimus), a cell cycle inhibitor (commonly mycophenolate mofetil), and corticosteroids. ${ }^{7}$ Due to a higher perceived risk for rejection episodes than other solid organ transplant recipients, lung transplant recipients generally receive more intense immunosuppression regimens. ${ }^{85}$ Initial trough level targets for tacrolimus are typically $10-20 \mathrm{mg} / \mathrm{mL}$. Initial dosing for prednisone is typically $0.5-1.0 \mathrm{mg} / \mathrm{kg} / \mathrm{d}$, tapering over the course of the first year. Nearly all patients remain on steroids at 1 and 5 y post-transplant. Induction immunotherapy at the time of transplant is used in $>70 \%$ of pediatric lung patients. Most receive an interleukin-2 receptor antagonist (ie, basiliximab), and the remainder receive a polyclonal agent (anti-lymphocyte or anti-thymocyte globulin). ${ }^{7}$

\section{Antimicrobial Regimen}

Most pediatric lung transplant patients receive intravenous antibiotics for 7-10 d starting immediately after transplant based on their pre-transplant airway colonization and modified based on donor information as well as cultures obtained in the immediate post-transplant period. Prophylaxis for opportunistic infections includes antifungal prophylaxis with voriconazole or a similar agent. ${ }^{86}$ Pneumocystis jirovecii (carinii) prophylaxis with trimethoprim/sulfamethoxazole and oral nystatin for Candida prophylaxis. Ganciclovir (or acyclovir when donor and recipient are cytomegalovirus-negative) is given as antiviral prophylaxis for cytomegalovirus and herpes simplex virus.
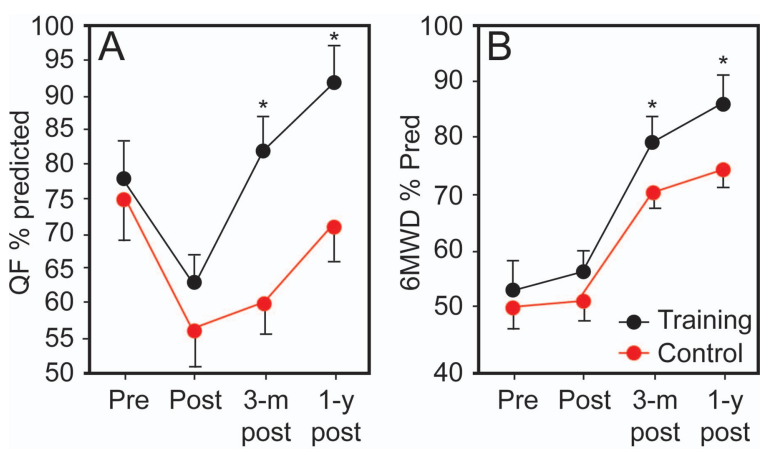

Fig. 4. Maximal isometric quadriceps strength (QF) (A) and 6-min walk distance (6MWD) (B) expressed as percentage of normative reference values specific to the demographic characteristics of participants (percent predicted) in a cohort of subjects that was longitudinally assessed before lung transplantation (Pre), immediately after hospital discharge (Post), and 3 months (3-m post) and 12 months (1-y post) after lung transplantation. One part of the cohort was randomly allocated to receive a supervised exercise training program during the first 3 months following hospital discharge (training); the other group (control) received usual care. Error bars denote standard error. * Statistical significance. Data from Reference 86.

\section{Rehabilitation}

There is limited literature to guide decision making regarding rehabilitation during the immediate post-transplant period. However, general principles regarding treatment in postoperative patients admitted to an ICU, including active lower-limb resistance training and early active muscle training, are likely to be of benefit. ${ }^{60}$

There have been 2 controlled studies in adults that assessed the impact of rehabilitation in the first year following hospital discharge. Langer et al ${ }^{87}$ compared 18 subjects who received 12 weeks of high-intensity, symptom-guided, lower-limb endurance and resistance training starting immediately after hospital discharge with 16 subjects receiving standard medical care. Subjects in the treatment group had higher peak work rate during a maximal incremental cardiopulmonary cycle exercise test, longer 6-min walk distance, increased quadriceps strength, and greater participation in daily physical activity compared with controls (Fig. 4). A second study found improved lumbar bone mineral density in 8 adult subjects receiving a supervised 6-month lumbar extension exercise training program beginning 8 weeks after discharge compared with 8 control subjects receiving usual care. ${ }^{88}$

One study involving children found improvements in 6-min walk distance distances at 3 months and at $1 \mathrm{y}$ in pediatric heart and lung transplant recipients who participated in an exercise program 3 times/week after transplant. ${ }^{89}$ The authors acknowledge the limitation of their decision to not include a control group in this study because it was performed in the context of an existing pro- 
gram. Optimal strategies for rehabilitation after lung transplantation remain to be identified.

\section{Monitoring}

Once discharged from the transplant hospitalization, patients are monitored closely in the out-patient environment. In the author's center, patients are seen twice weekly with laboratory evaluation and spirometry for at least a month post-transplant and then once weekly until the 3month time point. Patients are provided with home spirometry equipment (typically a handheld spirometer) and pulse oximetry and expected to monitor these daily in the early months post-transplant. Patients return for evaluation and surveillance biopsy every 3 months for the first year and then at 18 months and $2 \mathrm{y}$. Patients return for evaluation with biopsy based on clinical indications every 6 months thereafter.

\section{Outcomes and Risk Factors}

\section{Survival}

The most recent ISHLT registry report (for patients transplanted between January 1990 and June 2013) demonstrated survival after pediatric lung transplantation comparable with that in adults. Median survivals were 5.3 and $5.6 \mathrm{y}$, respectively $(P=.14) .^{7}$ Although 5 -y survival rates for pediatric recipients have demonstrated statistically significant improvement from $42.3 \%$ in the early era (1988$1999)$ to $56.4 \%$ in the recent era (2008-2013) when halflife conditional on survival to $1 \mathrm{y}$ is examined, no significant difference is seen when comparing eras. This observation suggests that early mortality improvements are primarily responsible for the era effect. Although survival curves continue to demonstrate the poorest overall survival in adolescents, including curves conditional on survival to $1 \mathrm{y}$, in contrast to prior reports, ${ }^{90}$ the differences do not reach statistical significance in the most recent report (Fig. 5). ${ }^{7}$

Retransplantation has become a more frequent occurrence since the implementation of the Lung Allocation System, ${ }^{25,91}$ probably as a result of shortened waiting times for children age $12 \mathrm{y}$ and older and improved survival in the recent era. ${ }^{92}$ Nonetheless, a recent registry report suggests caution, with poor (36\%) 5-y survival. ${ }^{91}$ Appropriate candidate selection for retransplant will remain an important area for investigation.

\section{Causes of Death}

Causes of death are time-dependent. The most recent ISHLT report shows that graft failure (including technical failure) is the most common cause of death in the first
$30 \mathrm{~d}$, followed by "cardiovascular" and "other." From $30 \mathrm{~d}$ to $1 \mathrm{y}$, infection is the primary cause of death, followed by graft failure and multiple-organ failure. Beyond $1 \mathrm{y}$, chronic allograft dysfunction (denoted as bronchiolitis) accounts for roughly $40 \%$ of deaths, followed by graft failure and infection. ${ }^{7}$ The distribution of death causes has not changed substantially over the course of time, reinforcing the importance of developing effective therapies for chronic lung allograft dysfunction.

Factors with increased risk for 5-y mortality include earlier transplant era, mechanical ventilation at the time of transplant, and diagnosis of CF. ${ }^{7}$ The significance of mechanical ventilation as a risk factor is less clear in infants. ${ }^{69}$

\section{Adolescence}

The observation that outcomes in adolescents are poorer than those in younger children is consistent with prior reports and is observed across all transplanted organs. ${ }^{93}$ Postulated risks include risk-taking behavior, including non-adherence with medical therapy, leading to an increased incidence of late acute rejection, graft failure, and mortality. ${ }^{94,95}$ Issues related to adherence in adolescence may be magnified during care transitions. Adding a new care environment and often a new insurance provider onto the existing challenges of adolescence may lead to poor medical outcomes. ${ }^{96}$ Successful transition depends on effective communication between the pediatric and adult care providers. ${ }^{97,98}$ Given current adolescent outcomes, it is clear that transition and adherence remain important areas for active study in pediatric transplantation. ${ }^{99,100}$

\section{Complications}

Lung transplant complications occur in 3 general phases. Immediately post-transplant, the primary complications are technical surgical issues and problems arising from the condition of the recipient or the allograft at the time of implantation. In addition to persistent surgical complications, the early phase (1-3 months) is dominated by issues related to the immune response to the allograft, mechanical complications related to the surgical procedure, and adverse effects of immunosuppression (particularly infection). The latter issues continue during in the late phase (beyond 3 months) and also include chronic complications related to the immune response, such as obliterative bronchiolitis and immunosuppression (ie, malignancy).

The depth and breadth of lung allograft rejection is the most important reason that long-term lung transplant outcomes are worse than those of other solid organ transplant recipients. Postulated mechanisms include the lung allograft providing a larger number of antigen-presenting cells that reside in the pulmonary vasculature and lymphatic 

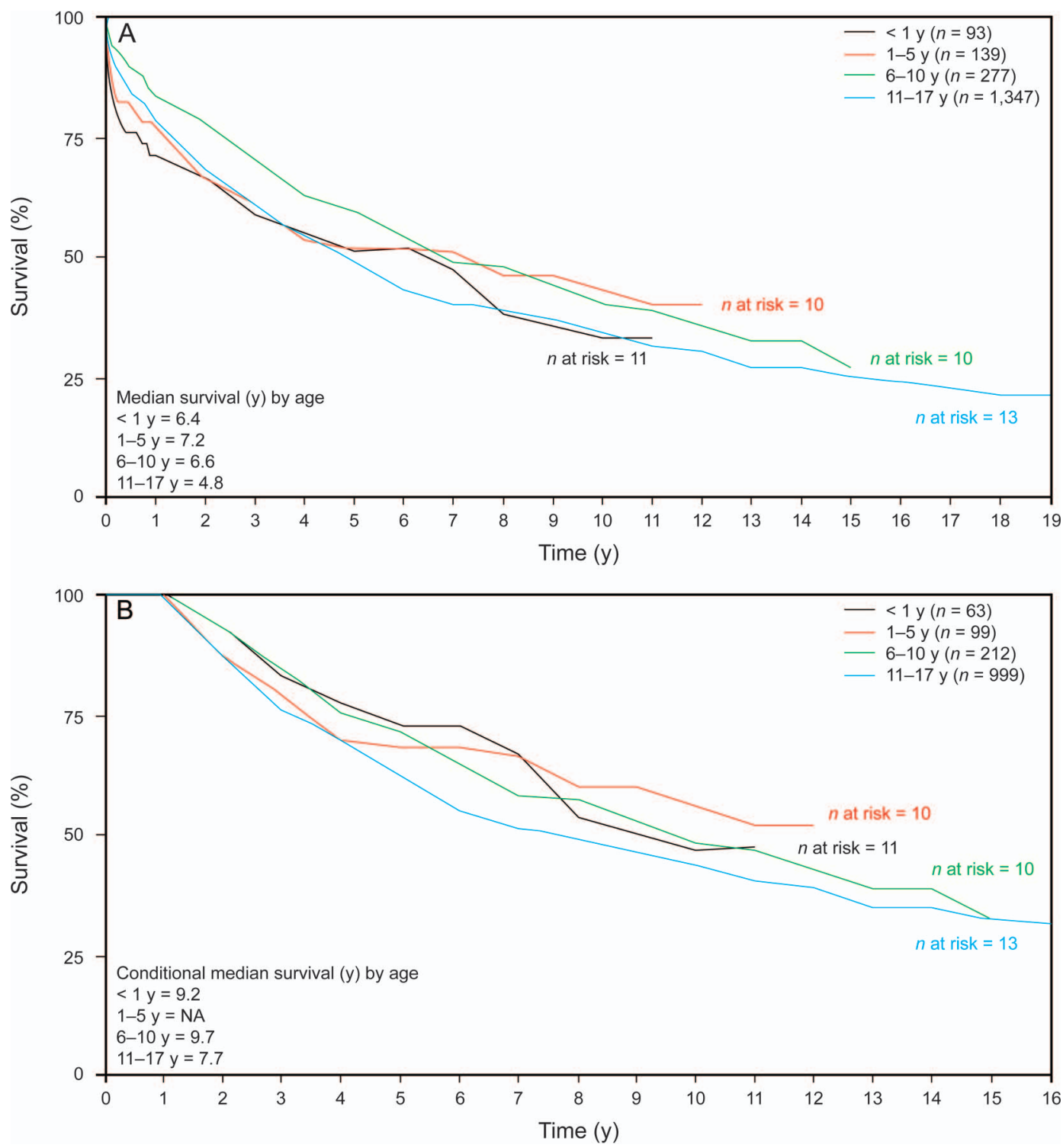

Fig. 5. A: Comparison of pediatric lung transplant survival between different age groups. B: Comparison of pediatric lung transplant survival between different age groups conditional on recipient survival to $1 \mathrm{y}$. Based on data reported to the International Society for Heart and Lung Transplant registry from January 1990 to June 2013. From Reference 7, with permission.

system; the fact that the airways and lung parenchyma are continuously exposed to environmental irritants, toxins, and pathogens; and the fact that the efficacy of the adaptive immune response is enhanced by virtue of the lungs receiving the entire cardiac output. ${ }^{101}$

\section{Immediate Post-Transplant Phase}

Because most pediatric lung transplant procedures are performed during cardiopulmonary bypass or ECMO, bleeding in the thoracic cavity or at the vascular anastomoses is not uncommon, especially in patients who have had prior thoracotomy or pleurodesis. ${ }^{102}$ Vascular anasto- motic complications may become apparent due to hypotension and/or radiographic abnormalities. The left atrial anastomosis or the pulmonary veins may be a site of thrombus formation. ${ }^{103}$ Perfusion scintography and echocardiography immediately post-transplant are often used to evaluate the patency of the vascular anastomoses.

Flexible bronchoscopy may be used in the immediate post-transplant period to assess the integrity of the airway anastomosis and to obtain cultures. Dehiscence at the bronchial anastomoses, although rare since the development of techniques to cover the anastomosis with vascularized tissue, may require an urgent return to the operating room. ${ }^{81,104,105}$ 
Hyperacute rejection, caused by preformed recipient antibodies binding to donor human leukocyte antigen (HLA) molecules on the vascular endothelium, is a rare, potentially catastrophic complication that can occur within hours of transplant. Hyperacute rejection leads to vascular damage, obstruction, and severe graft ischemia. Hyperacute rejection is preventable by performing a crossmatch with donor cells and recipient serum before transplant, ${ }^{106}$ but because the logistics of organ allocation (including distance between donor and recipient) generally preclude prospective crossmatching, screening the recipient for antiHLA antibodies and avoiding donors with related antigens ("virtual crossmatching") is the most commonly used approach to prevent hyperacute rejection. In cases where virtual crossmatch does not effectively predict the true crossmatch, treatment involves early initiation of plasmapheresis.

Primary graft dysfunction is the most common complication seen during the first post-transplant week. ${ }^{107,108}$ Primary graft dysfunction with incidence related to the duration of ischemia before implantation, is thought to be caused by generation of hydroxyl radicals and pro-inflammatory cytokines accumulating during graft ischemia. ${ }^{109-111}$ Primary graft dysfunction effects may range from mild, noncardiogenic pulmonary edema to fulminant graft failure with diffuse alveolar damage. Primary graft dysfunction is graded on a scale of 1 to 3 daily for the first $72 \mathrm{~h}$ posttransplant based on oxygenation index and the presence of diffuse infiltrates on chest imaging. ${ }^{108}$ Primary graft dysfunction therapy is primarily supportive and includes fluid restriction and avoidance of barotrauma. ${ }^{112}$ Severe cases may benefit from ECMO support. ${ }^{113,114}$ Retransplantation for primary graft dysfunction is associated with poor outcomes. ${ }^{115}$

\section{Early Phase}

\section{Immune Complications}

Acute Rejection. Acute rejection is the most common form of allograft rejection, affecting a majority of lung transplant recipients. Acute rejection is most commonly seen during the first 3 months (perhaps related to the halflife of donor-derived dendritic cells delivered with the graft) but can be diagnosed even 2-3 y later. ${ }^{101}$ Younger transplant recipients $(<3$ y of age) appear to have a lower risk for acute rejection than older children or adults.6,69,116 Acute rejection mimics pulmonary infection with cough, fever, dyspnea, hypoxemia, and tachypnea. Crackles may be evident on chest auscultation. Chest radiograph may show infiltrates, often perihilar, and spirometry may show an obstructive pattern. During the first 3 months posttransplant, evaluation of this clinical picture would typically include bronchoscopy, bronchoalveolar lavage, and transbronchial biopsy to evaluate for both infection and acute rejection. Findings on histology include perivascular lymphocytic infiltrates with or without airway inflammation and are graded A1 to A4 according to the ISHLT grading system. ${ }^{117-119}$ Because acute rejection may also be asymptomatic, many transplant centers perform surveillance bronchoscopy during the first $12-18$ months. The use of surveillance biopsies during the first post-transplant year is supported by data suggesting that a single episode of minimal acute rejection (A1), typically asymptomatic, is an independent risk factor for chronic allograft rejection. ${ }^{120,121}$ However, this finding was not confirmed in a multi-center analysis of pediatric lung transplant recipients. ${ }^{122}$

Acute rejection grade A2 and above is typically treated with $10 \mathrm{mg} / \mathrm{kg}$ intravenous methylprednisolone daily for $3 \mathrm{~d}$ and repeat biopsies 2 weeks later. When acute rejection persists on follow-up biopsies, augmented immunosuppression with antithymocyte globulin may be used, especially if the acute rejection grade is increased.

Humoral Rejection. A less common and more recently recognized immunologic complication of lung transplantation is antibody-mediated rejection. Antibody-mediated rejection may appear similar to both infection and acute rejection; patients may have dyspnea, pulmonary infiltrates, and decreased lung function. Specific criteria for diagnosis remain somewhat elusive. The presence of circulating donor-specific HLA antibodies (identified using solid-phase flow cytometry techniques), alveolar capillary complement deposition, and capillaritis in the setting of allograft dysfunction is generally sufficient evidence, ${ }^{123}$ although a 2012 ISHLT consensus statement includes a much broader set of histologic findings felt to be consistent with antibodymediated rejection (including all other types of rejection) if in addition donor-specific HLA antibodies are present and capillary complement deposition positivity is present in $>50 \%$ of interstitial capillaries. ${ }^{124}$

There is no consensus on treatment of humoral rejection. Pulse steroids, plasmapheresis, intravenous immunoglobulin, and B-cell-directed therapy (cytoxan or rituximab) are used, often in combination. ${ }^{125}$ The proteasome inhibitor bortezomib (which targets plasma cells) and the complement inhibitor eculizumab are also considered in the treatment of antibody-mediated rejection. ${ }^{126,127}$

\section{Airway Clearance}

Airway clearance following lung transplantation can be affected by airway structural changes, direct or indirect effects on respiratory system innervation, and medication adverse effects. Although the native lung has a dual blood supply (pulmonary and bronchial arteries), in most cases, the bronchial arteries are not reconnected following transplant. For this reason, the airway anastomoses are particularly vulnerable to ischemia. Although transplant surgeons try to improve the blood supply by covering the 
anastomosis with pericardial or peribronchial lymphatic tissue from the donor and recipient, this area remains particularly vulnerable in the immediate post-transplant period to sloughing and resultant impairment of mucus clearance. Some centers advocate for bronchial artery reanastomosis to reduce this effect. In a single-center study, anastomosis problems were reduced compared with conventional therapy. ${ }^{128}$

Other complications that can occur at the site of the airway anastomoses include dehiscence, which has fortunately has become rare since the development of techniques to cover the anastomosis with vascularized tissue $81,104,105$; fibrotic strictures; excessive granulation tissue; or airway collapse at the site of the anastomosis. All of these can impair mucus clearance at that level. Despite the smaller size of pediatric airways, airway complications occur at a frequency comparable with that seen in adult lung transplant recipients. ${ }^{129,130}$ Postulated mechanisms to explain the development of anastomotic narrowing include donor airway ischemia, impaired airway healing, and barotrauma in instances where recipients require prolonged mechanical ventilation. ${ }^{129}$ When stenosis of the airway lumen leads to significant air-flow obstruction or recurrent infections, it may be treated with bronchoscopic balloon dilatation or stent placement, although the latter is often fraught with complications, including recurrent granulation tissue, mucus plugging, and inadvertent dislodgement. Metallic expandable stents are generally avoided in children because of the formation of granulation tissue and limited potential for expansion to accommodate growth and significant potential for complication during removal. ${ }^{131}$ Silicone rubber stents may be used in children but are more easily dislodged or obstructed with mucus. ${ }^{130}$ More recently, biodegradable stents have been developed that are retained long enough to allow resolution of stenosis but subsequently disappear, allowing for airway growth. ${ }^{132}$

Other surgical complications include phrenic or recurrent laryngeal nerve injury, leading to diaphragmatic or vocal cord dysfunction, respectively. Both can impair mucus clearance through alteration in pulmonary mechanics. These may resolve over time, but for hemidiaphragm paresis with recurrent pneumonia, plication of the affected diaphragm may be considered.

Mucus clearance can also be impaired as a result of poor cough as a result of multiple factors. The afferent and efferent innervation of the lungs is disrupted at the time of transplant, leading to impairment of the cough reflex. Although it was initially thought that reinnervation does not occur, a 2012 study suggests otherwise. ${ }^{133}$ Pain in the immediate postoperative period can further impair cough. Finally, injury of the phrenic nerves or recurrent laryngeal nerve may occur during the surgical dissection, causing diaphragmatic or vocal cord dysfunction. Persistent diaphragm paresis may require plication.

Finally, even well after effective healing of the airway mucosa, there is evidence that lung transplant continues to result in impaired mucociliary clearance. ${ }^{134}$ This may be due in part to diminished ciliary beat frequency ${ }^{135,136}$ or other epithelial abnormalities, perhaps an adverse effect of immunosuppressant drugs. The calcineurin inhibitors and cell cycle inhibitors commonly used in lung transplant recipients have been shown to diminish ciliary beat frequency in animal studies. Although these effects may diminish as calcineurin inhibitor dose is deceased in the months following transplant, one small study has suggested that albuterol may mitigate these effects. ${ }^{137}$

Although many patients benefit from institution of airway clearance measures following transplantation, there have been no studies to identify optimal mucus clearance strategies to be used after lung transplantation. At the author's center, patients with CF are generally counseled to continue airway clearance measures they used before transplant (eg, chest physiotherapy, oscillatory PEP, high-frequency chest-wall oscillation, intermittent percussive ventilation) to manage symptoms with plans to wean as the airways heal post-transplant. Non-CF patients have airway clearance prescribed based on post-transplant symptoms.

Infection. Infection poses a risk for lung transplant recipients immediately after transplant throughout the life of the graft. Nonetheless, the incidence of infection is highest in the first weeks to months after transplant. Contributing factors include the risk of nosocomial infection associated with surgery and ventilator support; immunosuppression (highest in the first few months post-transplant); infections present in the donor at the time of procurement; and disruption of pulmonary lymphatics, leading to impaired trafficking of immune effector cells to regional lymph nodes. ${ }^{138}$ In addition, as noted above, disruption of afferent and efferent lung innervation leading to diminished cough response, airway injury at the time of procurement, interruption of the normal mucociliary ladder at the level of the airway anastomoses add to the risk of infection. Although prophylactic antibiotics are commonly given in the perioperative period, recipient colonization (particularly in patients with $\mathrm{CF}$ ) and donor infection, including unsuspected viral infection, may lead to early morbidity. Early viral infection is more common and significant in infants and toddlers, perhaps due to immaturity of their immune system. ${ }^{12}$ Patients with CF may develop bacteremia due to seeding of the blood or mediastinum with airway flora during explantation. Although in the past, pre-transplant sinus surgery and irrigation was performed because of concern that chronic sinus disease would infect the allograft, ${ }^{139,140}$ a retrospective analysis of sinus surgery in 
subjects with CF undergoing transplant did not demonstrate survival benefit. ${ }^{141}$

Beyond the first week, infections with community and nosocomial bacteria as well as opportunistic pathogens, such as pneumocystis, Candida, and cytomegalovirus, become more prevalent. Patients mismatched for cytomegalovirus (ie, donor positive, recipient negative) are at particular risk for cytomegalovirus disease during this early phase.

Cytomegalovirus may present with a viral syndrome including fever and leukopenia or significant pneumonitis and viremia and gastrointestinal tract involvement. Cytomegalovirus pneumonitis may include cough, fever, chills, respiratory distress, crackles, and diffuse interstitial infiltrates. Systemic cytomegalovirus is diagnosed through identification in the bloodstream (typically with polymerase chain reaction). Cytomegalovirus pneumonitis is diagnosed by the positive cytomegalovirus immunohistochemistry on transbronchial biopsy or lung biopsy coupled with clinical findings. Bronchoalveolar lavage (BAL) positive for cytomegalovirus polymerase chain reaction is not uncommon in asymptomatic patients and is felt to be related to viral shedding. Treatment of systemic cytomegalovirus or cytomegalovirus pneumonitis typically involves the use of intravenous ganciclovir for 2-6 weeks. Cytomegalovirus hyperimmune globulin may also be added, particularly in severe cases. After completion of intravenous treatment, oral valganciclovir prophylaxis may be administered for 2-3 months. Although before the availability of ganciclovir, mismatched recipients had a $75 \%$ or higher incidence of cytomegalovirus in the first 6 months after transplant, ${ }^{142}$ current prophylaxis and treatment strategies have reduced the incidence of cytomegalovirus pneumonitis and limited its significance as a risk factor for chronic rejection. ${ }^{143,144}$

Similar to cytomegalovirus, effective prophylaxis with trimethoprim/sulfamethoxazole generally prevents the development of $P$. jirovecii (carinii) pneumonia. Nonetheless, patients with acute onset of fever, respiratory distress, interstitial infiltrates, and hypoxemia out of proportion to radiographic disease should prompt the consideration of $P$. jirovecii pneumonia. Diagnosis is made by identifying organisms with silver or fluorescent staining of BAL specimens. $P$. jirovecii pneumonia is treated with intravenous trimethoprim/sulfamethoxazole. Although inhaled pentamidine was commonly used as an alternative to trimethoprim/sulfamethoxazole in the past, the availability of prophylaxis alternatives in patients with allergy, such as atovaquone, and the availability of intravenous pentamidine for treatment have reduced the use of inhaled pentamidine.

Respiratory viral infections, as alluded to above, are particularly problematic in young children. Increased exposure from daycare, school, and siblings as well as less well-developed immunity may contribute to this finding.
Adenovirus ${ }^{145}$ and paramyxoviruses, including parainfluenza and respiratory syncytial virus, have all been associated with significant lung injury or mortality ${ }^{146,147}$ and are risk factors for the development of chronic allograft dysfunction. ${ }^{148}$ For these reasons, viral infections are often aggressively treated with cidofovir and ribavirin as indicated. ${ }^{147,149,150}$

Finally, infections with fungal organisms and atypical mycobacteria also pose significant risk for post-transplant infection. ${ }^{151,152}$ Many centers use fungal prophylaxis in the immediate post-transplant period. ${ }^{86}$ Currently recommended prophylactic strategies include voriconazole intravenously or orally given for 4-6 months, inhaled amphotericin B liposomal 3 times weekly for 2 months and then once weekly, or daily inhaled amphotericin B standard formulation. ${ }^{153}$

Surgical Complications and Medication Adverse Effects. There are many non-pulmonary complications that become apparent in the early post-transplant phase. These include gastrointestinal dysmotility and/or gastroparesis, which occurs with an incidence of up to 50\%.154 Supraventricular arrhythmias, including supraventricular tachycardia, atrial flutter, and atrial fibrillation, associated with the left-atrial cuff suture line are not uncommon. Typically, these arrhythmias are not associated with hemodynamic compromise, respond to conventional therapy, and are self-limited. ${ }^{155}$ There are a multitude of adverse effects related to the immunosuppression regimen. Calcineurin inhibitors cause hypertension and nephrotoxicity ${ }^{156}$ Calcineurin inhibitors are also associated with neurologic symptoms ranging from headache and sleep disturbance to seizures and posterior reversible encephalopathy syndrome. ${ }^{157,158}$ Diabetes, particularly in patients with $\mathrm{CF}$ and perhaps precipitated by the use of tacrolimus, is present in $>35 \%$ of long survivors of lung transplantation. ${ }^{90,159}$ Cell cycle inhibitors lead to leukopenia, and adverse effects of systemic corticosteroids include hypertension, cataracts, osteoporosis, and insulin resistance.

\section{Late Phase}

In addition to the persistence of early-phase complications, including infection, drug toxicity, acute cellular and humoral rejection, and airway anastomotic narrowing, the primary complications appearing in the late phase include post-transplant lymphoproliferative disease and bronchiolitis obliterans, 2 potentially life-threatening complications.

Post-Transplant Lymphoproliferative Disease. The incidence of malignancy after lung transplantation is $5.6 \%$ at $1 \mathrm{y}$ and $11.2 \%$ at $5 \mathrm{y}$. The vast majority of malignancies are post-transplant lymphoproliferative disease..$^{90}$ Post- 
transplant lymphoproliferative disease is typically an Epstein-Barr virus-driven lymphoma. ${ }^{160,161}$

Diagnosis of post-transplant lymphoproliferative disease requires a high index of suspicion because presenting symptoms are often vague and mimic other disease processes. Post-transplant lymphoproliferative disease can be asymptomatic or can present with symptoms suggestive of pulmonary infection or with nonspecific symptoms, particularly if involving extrapulmonary organs. Post-transplant lymphoproliferative disease typically involves the allograft during the first year, ${ }^{162}$ presenting with one or more round or ovoid pulmonary nodules. ${ }^{163}$ Beyond the first year, extrapulmonary post-transplant lymphoproliferative disease may involve the gastrointestinal tract, the skin, and lymphatic tissue, including the nasopharynx. ${ }^{164,165}$ Screening for post-transplant lymphoproliferative disease involves serial. quantitative polymerase-chain-reaction measurements of Epstein-Barr virus. ${ }^{166}$ Although the presence of elevated Epstein-Barr virus as measured by polymerase chain reaction may be treated with reduced immunosuppression, ${ }^{167}$ caution with this approach is recommended in children. ${ }^{168}$ Alternatively, additional testing with positron emission tomography may be useful as a sensitive and specific test for post-transplant lymphoproliferative disease. ${ }^{169}$ Once identified, histologic diagnosis and staging are important components of the diagnostic and prognostic process. Monomorphous post-transplant lymphoproliferative disease has a worse prognosis. ${ }^{170}$ In the current era, patients with CD20-positive post-transplant lymphoproliferative disease are treated according to the Children's Oncology Group protocol ANHL 0221 (including Rituximab, an anti-CD20 monoclonal antibody shown to be effective in non-Hodgkin's lymphoma, low-dose cytoxan, and prednisone). ${ }^{171}$

\section{Chronic Lung Allograft Dysfunction and Obliterative}

Bronchiolitis. Long-term survival rates in lung transplantation are worse than for other solid organ transplants. Five-year survival in lung transplant recipients is $<60 \%$ compared with $>70 \%$ in heart and liver and $>80 \%$ in kidney transplant recipients. ${ }^{172-175}$ The main reason for this disparity is chronic graft failure, most commonly due to obliterative bronchiolitis or bronchiolitis obliterans syndrome. ${ }^{176,177}$ Obliterative bronchiolitis is the leading cause of death after the first year post-transplant. In children, only $40 \%$ of survivors are free of bronchiolitis obliterans at 6 y. ${ }^{90}$ First recognized as a primary cause of death in lung transplant recipients, nearly $30 \mathrm{y}$ ago, the etiology of obliterative bronchiolitis remains elusive, and no uniformly effective treatment options exist. ${ }^{178}$

Obliterative bronchiolitis is primarily a histologic diagnosis in the context of irreversible obstructive graft dysfunction. Generally, plain chest imaging is unrevealing in these cases. CT imaging may reveal bronchiectasis and air
Table 4. Classification of Bronchiolitis Obliterans Syndrome

\begin{tabular}{|c|c|}
\hline $\begin{array}{l}\text { Bronchiolitis Obliterans } \\
\text { Syndrome Grade }\end{array}$ & Pulmonary Function Measurements \\
\hline 0 & $\begin{array}{l}\mathrm{FEV}_{1}>90 \% \text { of baseline and } \\
\mathrm{FEF}_{25-75 \%}>75 \% \text { of baseline }\end{array}$ \\
\hline $0-\mathrm{p}$ & $\begin{array}{l}\mathrm{FEV}_{1}=81-90 \% \text { of baseline and/or } \\
\mathrm{FEF}_{25-75 \%}<75 \% \text { of baseline }\end{array}$ \\
\hline 1 & $\mathrm{FEV}_{1}=66-80 \%$ of baseline \\
\hline 2 & $\mathrm{FEV}_{1}=51-65 \%$ of baseline \\
\hline 3 & $\mathrm{FEV}_{1} \leq 50 \%$ of baseline \\
\hline \multicolumn{2}{|c|}{$\begin{array}{l}\text { Data from Reference } 177 . \\
\mathrm{FEF}_{25-75 \%}=\text { forced expiratory flow during the middle half of the } \mathrm{FVC} \text { maneuver }\end{array}$} \\
\hline
\end{tabular}

trapping on high-resolution computed tomography, ${ }^{179}$ and ventilation imaging may reveal xenon retention. ${ }^{180}$ Fibroproliferative obliteration of small airways, dense eosinophilic sub-mucosal fibrosis in the bronchioles, and partial (concentric or eccentric) or complete luminal occlusion are seen on lung biopsy. Destruction of the airway wall and surrounding smooth muscle may also be present. ${ }^{119}$ ISHLT pathologic grading schemes originally distinguished between sub-total and total ${ }^{115}$ and active versus inactive ${ }^{118}$ forms. However, the current ISHLT grading defines only $\mathrm{C} 0$ (no evidence of obliterative bronchiolitis) or $\mathrm{C} 1$ (obliterative bronchiolitis present). ${ }^{119}$ Exclusion of obliterative bronchiolitis by transbronchial biopsy is not possible because obliterative bronchiolitis does not affect all small airways. Diagnosis can even be missed on open lung biopsy. In our experience, obliterative bronchiolitis sometimes presents with alveolar hyperinflation, suggesting the presence of upstream obstruction. For these reasons, a clinical correlate, bronchiolitis obliterans syndrome, was proposed in 1993. ${ }^{176,177}$ A bronchiolitis obliterans syndrome grade of $\geq 1$ (reflecting a decline in $\mathrm{FEV}_{1}>20 \%$ from the post-transplant best) is treated as if obliterative bronchiolitis is present (Table 4).

Over the past few years, it has become apparent that the classic obliterative bronchiolitis picture of chronic graft failure is part of a broader spectrum of chronic lung allograft dysfunction, characterized by a loss of lung function $\left(\mathrm{FEV}_{1}\right)$ from the best post-transplant baseline. ${ }^{181} \mathrm{It}$ is now known that a subset (approximately 30\%) of chronic lung allograft dysfunction patients, typically with BAL neutrophilia, will have improvement in $\mathrm{FEV}_{1}$ following administration of a macrolide, such as azithromycin. ${ }^{182}$ These patients are typically referred to as having "neutrophilicreversible allograft dysfunction" or "azithromycin-responsive allograft dysfunction." Another subset (approximately $30 \%$ ) of chronic lung allograft dysfunction patients may develop a restrictive pulmonary function abnormality, denoted "restrictive allograft syndrome" 183 associated with persistent infiltrates on chest imaging, subpleural thicken- 
ing on CT, and pleuroparenchymal fibroelastosis and obliterative bronchiolitis on histopathology. Although uniformly accepted pulmonary function criteria are yet to be established, typically, patients with a persistent decrease in FVC or total lung capacity associated with chronic pulmonary infiltrates are considered to have restrictive allograft syndrome. Patients with restrictive allograft syndrome typically have a shorter survival (6-18 months) compared with 3-5 y for patients with bronchiolitis obliterans syndrome. ${ }^{183,184}$

Because patients with azithromycin-responsive allograft dysfunction often develop bronchiolitis obliterans syndrome or restrictive allograft syndrome and patients with restrictive allograft syndrome generally have histologic findings consistent with obliterative bronchiolitis/bronchiolitis obliterans syndrome, it is likely that these entities represent different manifestations of a single common pathologic pathway involving aberrant injury/repair mechanisms of the lung parenchyma and supporting vasculature.

There have been many studies seeking to identify risk factors for the development of chronic lung allograft dysfunction. A comprehensive review of single-center studies of obliterative bronchiolitis/bronchiolitis obliterans syndrome found that acute rejection episodes occurring $>3$ months post-transplant and lymphocytic bronchitis/bronchiolitis, especially $>6$ months post-transplant, were the most consistent risk factors. ${ }^{185}$ Although cytomegalovirus was associated with the development of obliterative bronchiolitis/bronchiolitis obliterans syndrome before the wide availability of ganciclovir, it has not been a consistent risk factor in contemporary studies. ${ }^{142,143}$ Single-center analyses have identified anti HLA antibodies ${ }^{186,187}$ as well as $\alpha$ tubulin and collagen $\mathrm{V}$ autoantibodies as risk factors ${ }^{188,189}$ Early expression of HLA-G in the allograft is associated with stable graft function. ${ }^{190}$ In contrast, the presence of soluble HLA-G in BAL fluid is associated with bronchiolitis obliterans syndrome. ${ }^{191}$ Airway injury as a result of gastroesophageal reflux is also considered a risk factor. Fundoplication reduced the incidence of obliterative bronchiolitis/bronchiolitis obliterans syndrome in a single-center study. ${ }^{192,193}$ Community-acquired respiratory viruses, including paramyxoviruses, influenza, and adenovirus, have been implicated in obliterative bronchiolitis/bronchiolitis obliterans syndrome. ${ }^{194,195}$

Another previously described entity is acute fibrinoidorganizing pneumonia. Patients present acute or semi-acute onset of nonobstructive pulmonary function defects and bilateral ground-glass infiltrate associated with interlobular septal thickening, consolidation, or peripheral fibrosis. Histologically, acute fibrinoid-organizing pneumonia is characterized by peribronchiolar and alveolar fibrin deposition with minimal associated inflammation. ${ }^{196-198}$ Given the similarities with restrictive allograft syndrome, it is suspected that acute fibrinoid-organizing pneumonia may represent a precursor or more fulminant form of restrictive allograft syndrome. ${ }^{199}$

Infants and toddlers ${ }^{69}$ and children who have received living related lobar transplantation ${ }^{200,201}$ have a reduced risk of obliterative bronchiolitis/bronchiolitis obliterans syndrome. In contrast, immunosuppression non-adherence is a significant risk factor for obliterative bronchiolitis/bronchiolitis obliterans syndrome. ${ }^{202}$

Studies seeking to correlate risk factors to underlying physiologic mechanisms have implicated interleukin$17^{+} \mathrm{T}$ cell-mediated interleukin-8/CXCL-8-induced neutrophilic airway inflammation in azithromycin-responsive allograft dysfunction and lymphocytic bronchitis. ${ }^{203,204}$ Genetic studies have implicated several polymorphisms, primarily affecting the innate immune system, in the development of bronchiolitis obliterans syndrome. ${ }^{205-208}$ Patterns of cytokine, chemokine, and growth factor expression appear to be different in bronchiolitis obliterans syndrome and restrictive allograft syndrome, suggesting differing underlying mechanisms. Restrictive allograft syndrome is associated with distinct expression patterns of alveolar alarmins, increased BAL eosinophils, interleukin-6 and interferon $\gamma$-inducible protein 10 /chemokine ligand 10 , and interferoninducible T cell $\alpha$ chemokine/CXCL11. ${ }^{209,210}$ In contrast, patients with bronchiolitis obliterans syndrome have increased BAL neutrophils, defensins, tissue inhibitor of metalloproteinase- 1 and -2 , and total matrix metalloproteinase-2/3/7/8/9.211-213 Despite these findings, none of the identified biomarkers are sufficiently specific to provide a clear chronic lung allograft dysfunction diagnosis. ${ }^{199}$ Bronchiolitis obliterans syndrome has also been associated with profibrotic cytokines, such as transforming growth factor $\beta^{214}$ or platelet-derived growth factor. 215

Treatment of chronic lung allograft dysfunction is difficult. Approximately $30 \%$ of patients presenting with obstructive chronic lung allograft dysfunction respond to azithromycin. ${ }^{216}$ Those who do not respond generally receive altered or augmented immunosuppression as an initial treatment. Changing from cyclosporin A to tacrolimus may be beneficial (although most pediatric centers no longer use cyclosporin $\mathrm{A}$ as the primary calcineurin inhibitor). ${ }^{217}$ Agents such as antithymocyte globulin or OKT3 may be effective adjunctive therapy in some patients. ${ }^{218}$ Cyclophosphamide, ${ }^{219}$ methotrexate, ${ }^{220}$ and total lymphoid irradiation $^{221}$ have been beneficial in some patients. More recently, treatment with photopheresis has emerged as an important second-line therapy, ${ }^{222-224}$ although this may be more beneficial when initiated early and in patients with bronchiolitis obliterans syndrome as opposed to restrictive allograft syndrome. ${ }^{223-228}$ Nonetheless, disease progression may occur, often complicated by or worsened by infection. 


\section{Pediatric Lung Transplantation}

Retransplantation is generally presented as an option in patients with progressive decline in lung function and no other contraindications, particularly in the Lung Allocation System era of reduced waiting time. ${ }^{25}$ Nonetheless, this approach must be tempered by data suggesting that adult patients undergoing retransplantation for restrictive allograft syndrome have worse outcome than those with bronchiolitis obliterans syndrome (3-y survival of $34 \%$ compared with 68\%). ${ }^{229}$

\section{Summary}

In summary, pediatric lung transplant is a viable option for treatment of end-stage lung disease in children. However, long-term success is limited by limited availability of donor organs, debilitation as a result of chronic disease, complications leading to impaired mucus clearance and increased risk for infection, and, most importantly, chronic lung allograft dysfunction. Opportunities for investigation and innovation remain in all of these domains, including using ex vivo lung perfusion to increase the lung donor pool, using extracorporeal support strategies coupled with effective rehabilitation to effectively bridge patients to transplant, clarifying the benefit of airway clearance techniques in lung transplant recipients, and, most importantly, efforts toward understanding the underlying mechanisms of and developing effective therapies to prevent or treat the many presentations of chronic lung allograft dysfunction.

\section{REFERENCES}

1. Hardy JD, Webb WR, Dalton ML Jr, Walker GR Jr. Lung homotransplantation in man. JAMA 1963;186:1065-1074.

2. Reitz BA, Wallwork JL, Hunt SA, Pennock JL, Billingham ME, Oyer PE, et al. Heart-lung transplantation: successful therapy for patients with pulmonary vascular disease. N Engl J Med 1982; 306(10):557-564.

3. Grossman RF, Frost A, Zamel N, Patterson GA, Cooper JD, Myron PR, et al. Results of single-lung transplantation for bilateral pulmonary fibrosis: the Toronto Lung Transplant Group. N Engl J Med 1990;322(11):727-733.

4. Noyes BE, Kurland G, Orenstein DM, Fricker FJ, Armitage JM. Experience with pediatric lung transplantation. J Pediatr 1994;124(2): 261-268.

5. Métras D, Shennib H, Kreitmann B, Camboulives J, Viard L, Carcassonne $\mathrm{M}$, et al. Double-lung transplantation in children: a report of 20 cases: the Joint Marseille-Montréal Lung Transplant Program. Ann Thorac Surg 1993;55(2):352-356.

6. Sweet SC, Spray TL, Huddleston CB, Mendeloff E, Canter CE, Balzer DT, et al. Pediatric lung transplantation at St. Louis Children's Hospital, 1990-1995. Am J Respir Crit Care Med 1997;155(3): 1027-1035.

7. Goldfarb SB, Benden C, Edwards LB, Kucheryavaya AY, Dipchand AI, Levvey BJ, et al. The Registry of the International Society for Heart and Lung Transplantation: eighteenth official pediatric lung and heart-lung transplantation report-2015; focus theme: early graft failure. J Heart Lung Transplant 2015;34(10):1255-1263.
8. Benza RL, Miller DP, Barst RJ, Badesch DB, Frost AE, McGoon MD. An evaluation of long-term survival from time of diagnosis in pulmonary arterial hypertension from the REVEAL Registry. Chest 2012;142(2):448-456.

9. Cystic Fibrosis Foundation Patient Registry 2014 Annual Data Report. Bethesda, Maryland: Cystic Fibrosis Foundation; 2015. https://www.cff. org/2014_CFF_Annual_Data_Report_to_the_Center_Directors.pdf/. Accessed April 7, 2017.

10. Organ Procurement and Transplantation Network (OPTN) and Scientific Registry of Transplant Recipients (SRTR). OPTN \& SRTR 2011 Annual Data Report. Rockville, Maryland: United States Department of Health and Human Services; 2012. https://srtr.transplant. hrsa.gov/annual_reports/2011/pdf/2011_SRTR_ADR.pdf. Accessed April 7, 2017.

11. Sweet SC, Aurora P, Benden C, Wong JY, Goldfarb SB, Elidemir O, et al. Lung transplantation and survival in children with cystic fibrosis: solid statistics-flawed interpretation. Pediatr Transplant 2008; 12(2):129-136.

12. Bridges ND, Mallory GB, Huddleston CB, Canter CE, Spray TL. Lung transplantation in infancy and early childhood. J Heart Lung Transplant 1996;15(9):895-902.

13. Hamvas A, Nogee LM, Mallory GB Jr, Spray TL, Huddleston CB, August A, et al. Lung transplantation for treatment of infants with surfactant protein B deficiency. J Pediatr 1997;130(2):231-239.

14. Nogee LM, Dunbar AE 3rd, Wert SE, Askin F, Hamvas A, Whitsett JA. A mutation in the surfactant protein $\mathrm{C}$ gene associated with familial interstitial lung disease. N Engl J Med 2001;344(8):573-579.

15. Shulenin S, Nogee LM, Annilo T, Wert SE, Whitsett JA, Dean M. ABCA3 gene mutations in newborns with fatal surfactant deficiency. N Engl J Med 2004;350(13):1296-1303.

16. Maquet E, Costagliola S, Parma J, Christophe-Hobertus C, Oligny LL, Fournet JC, et al. Lethal respiratory failure and mild primary hypothyroidism in a term girl with a de novo heterozygous mutation in the TITF1/NKX2.1 gene. J Clin Endocrinol Metab 2009;94(1):197-203.

17. Faro A, Mallory GB, Visner GA, Elidemir O, Mogayzel PJ Jr, Danziger-Isakov L, et al. American Society of Transplantation executive summary on pediatric lung transplantation. Am J Transplant 2007; 7(2):285-292.

18. Aris RM, Routh JC, LiPuma JJ, Heath DG, Gilligan PH. Lung transplantation for cystic fibrosis patients with Burkholderia cepacia complex: survival linked to genomovar type. Am J Respir Crit Care Med 2001;164(11):2102-2106.

19. De Soyza A, McDowell A, Archer L, Dark JH, Elborn SJ, Mahenthiralingam E, et al. Burkholderia cepacia complex genomovars and pulmonary transplantation outcomes in patients with cystic fibrosis. Lancet 2001;358(9295):1780-1781.

20. Murray S, Charbeneau J, Marshall BC, LiPuma JJ. Impact of Burkholderia infection on lung transplantation in cystic fibrosis. Am J Respir Crit Care Med 2008;178(4):363-371.

21. Taylor JL, Palmer SM. Mycobacterium abscessus chest wall and pulmonary infection in a cystic fibrosis lung transplant recipient. J Heart Lung Transplant 2006;25(8):985-988.

22. Gilljam M, Scherstén H, Silverborn M, Jönsson B, Ericsson Hollsing A. Lung transplantation in patients with cystic fibrosis and Mycobacterium abscessus infection. J Cyst Fibros 2010;9(4):272-276.

23. Grady RM, Gandhi S, Sweet SC, Mao J, Huddleston CB. Dismal lung transplant outcomes in children with tetralogy of Fallot with pulmonary atresia compared to Eisenmenger syndrome or pulmonary vein stenosis. J Heart Lung Transplant 2009;28(11):12211225.

24. Egan TM, Murray S, Bustami RT, Shearon TH, McCullough KP, Edwards LB, et al. Development of the new lung allocation system in the United States. Am J Transplant 2006(5 Pt 2);6:12121227. 


\section{Pediatric Lung Transplantation}

25. Yusen RD, Shearon TH, Qian Y, Kotloff R, Barr ML, Sweet S, et al. Lung transplantation in the United States, 1999-2008. Am J Transplant 2010(4 Pt 2);10:1047-1068.

26. Sweet SC. Improving the lung allocation system: statistical significance does not guarantee predictive value. J Heart Lung Transplant 2010;29(7):756-758.

27. Sweet SC. Update on pediatric lung allocation in the United States. Pediatr Transplant 2009;13(7):808-813.

28. Kerem E, Reisman J, Corey M, Canny GJ, Levison H. Prediction of mortality in patients with cystic fibrosis. N Engl J Med 1992;326(18): 1187-1191.

29. Mayer-Hamblett N, Rosenfeld M, Emerson J, Goss CH, Aitken ML. Developing cystic fibrosis lung transplant referral criteria using predictors of 2-year mortality. Am J Respir Crit Care Med 2002;166(12 Pt 1):1550-1555.

30. Belkin RA, Henig NR, Singer LG, Chaparro C, Rubenstein RC, Xie SX, et al. Risk factors for death of patients with cystic fibrosis awaiting lung transplantation. Am J Respir Crit Care Med 2006; 173(6):659-666

31. Liou TG, Adler FR, Cox DR, Cahill BC. Lung transplantation and survival in children with cystic fibrosis. N Engl J Med 2007;357(21): 2143-2152.

32. Aurora P, Whitehead B, Wade A, Bowyer J, Whitmore P, Rees PG, et al. Lung transplantation and life extension in children with cystic fibrosis. Lancet 1999;354(9190):1591-1593.

33. Hofer M, Benden C, Inci I, Schmid C, Irani S, Speich R, et al. True survival benefit of lung transplantation for cystic fibrosis patients: the Zurich experience. J Heart Lung Transplant 2009;28(4):334-339.

34. Adler FR, Aurora P, Barker DH, Barr ML, Blackwell LS, Bosma $\mathrm{OH}$, et al. Lung transplantation for cystic fibrosis. Proc Am Thorac Soc 2009;6(8):619-633.

35. Clabby ML, Canter CE, Moller JH, Bridges ND. Hemodynamic data and survival in children with pulmonary hypertension. J Am Coll Cardiol 1997;30(2):554-560.

36. ok;2Sandoval J, Bauerle O, Gomez A, Palomar A, Martínez Guerra ML, Furuya ME. Primary pulmonary hypertension in children: clinical characterization and survival. J Am Coll Cardiol 1995;25(2): 466-474.

37. Leuchte HH, Holzapfel M, Baumgartner RA, Ding I, Neurohr C, Vogeser $\mathrm{M}$, et al. Clinical significance of brain natriuretic peptide in primary pulmonary hypertension. J Am Coll Cardiol 2004;43(5):764-770.

38. Lopes AA, Maeda NY. Circulating von Willebrand factor antigen as a predictor of short-term prognosis in pulmonary hypertension. Chest 1998;114(5):1276-1282.

39. Bendayan D, Shitrit D, Ygla M, Huerta M, Fink G, Kramer MR. Hyperuricemia as a prognostic factor in pulmonary arterial hypertension. Respir Med 2003;97(2):130-133.

40. Choong CK, Sweet SC, Guthrie TJ, Mendeloff EN, Haddad FJ, Schuler P, et al. Repair of congenital heart lesions combined with lung transplantation for the treatment of severe pulmonary hypertension: a 13-year experience. J Thorac Cardiovasc Surg 2005; 129(3):661-669.

41. Mendeloff EN, Huddleston CB. Lung transplantation and repair of complex congenital heart lesions in patients with pulmonary hypertension. Semin Thorac Cardiovasc Surg 1998;10(2):144-151.

42. Faro A, Hamvas A. Lung transplantation for inherited disorders of surfactant metabolism. NeoReviews 2008;9(10):e468-e476.

43. Langer D. Rehabilitation in patients before and after lung transplantation. Respiration 2015;89(5):353-362.

44. Myaskovsky L, Dew MA, McNulty ML, Switzer GE, DiMartini AF, Kormos RL, McCurry KR. Trajectories of change in quality of life in 12-month survivors of lung or heart transplant. Am J Transplant 2006;6(8):1939-1947.
45. Smeritschnig B, Jaksch P, Kocher A, Seebacher G, Aigner C, Mazhar S, Klepetko W. Quality of life after lung transplantation: a cross-sectional study. J Heart Lung Transplant 2005;24(4):474480 .

46. Langer D, Cebrià i Iranzo MA, Burtin C, Verleden SE, Vanaudenaerde BM, Troosters T, et al. Determinants of physical activity in daily life in candidates for lung transplantation. Respir Med 2012; 106(5):747-754.

47. Langer D, Gosselink R, Pitta F, Burtin C, Verleden G, Dupont L, et al. Physical activity in daily life 1 year after lung transplantation. J Heart Lung Transplant 2009;28(6):572-578.

48. Rochester CL. Pulmonary rehabilitation for patients who undergo lung-volume-reduction surgery or lung transplantation. Respir Care 2008;53(9):1196-1202.

49. Schwaiblmair M, Reichenspurner H, Müller C, Briegel J, Fürst H, Groh J, et al. Cardiopulmonary exercise testing before and after lung and heart-lung transplantation. Am J Respir Crit Care Med 1999; 159(4):1277-1283.

50. Pantoja JG, Andrade FH, Stoki DS, Frost AE, Eschenbacher WL, Reid MB. Respiratory and limb muscle function in lung allograft recipients. Am J Respir Crit Care Med 1999;160(4):1205-1211.

51. Reinsma GD, ten Hacken NHT, Grevink RG, van der Bij W, Koëter $\mathrm{GH}$, van Weert E. Limiting factors of exercise performance 1 year after lung transplantation. J Heart Lung Transplant 2006;25(11):1310-1316.

52. Mathur S, Reid WD, Levy RD. Exercise limitation in recipients of lung transplants. Phys Ther 2004;84(12):1178-1187.

53. van Adrichem EJ, Reinsma GD, van den Berg S, van der Bij W, Erasmus ME, Krijnen WP, et al. Predicting 6-minute walking distance in recipients of lung transplantation: longitudinal study of 108 patients. Phys Ther 2015;95(5):720-729.

54. Williams TJ, McKenna MJ. Exercise limitation following transplantation. Compr Physiol 2012;2(3):1937-1979.

55. Schakman O, Kalista S, Barbé C, Loumaye A, Thissen JP. Glucocorticoid-induced skeletal muscle atrophy. Int J Biochem Cell Biol 2013;45(10):2163-2172.

56. Schakman O, Gilson H, Thissen JP. Mechanisms of glucocorticoidinduced myopathy. J Endocrinol 2008;197(1):1-10.

57. Sakuma K, Yamaguchi A. The functional role of calcineurin in hypertrophy, regeneration, and disorders of skeletal muscle. J Biomed Biotechnol 2010;2010:721219.

58. Sanchez H, Zoll J, Bigard X, Veksler V, Mettauer B, Lampert E, et al. Effect of cyclosporin A and its vehicle on cardiac and skeletal muscle mitochondria: relationship to efficacy of the respiratory chain. Br J Pharmacol 2001;133(6):781-788.

59. Mathur S, Janaudis-Ferreira T, Wickerson L, Singer LG, Patcai J, Rozenberg D, et al. Meeting report: consensus recommendations for a research agenda in exercise in solid organ transplantation. Am J Transplant 2014;14(10):2235-2245.

60. Rochester CL, Fairburn C, Crouch RH. Pulmonary rehabilitation for respiratory disorders other than chronic obstructive pulmonary disease. Clin Chest Med 2014;35(2):369-389.

61. Gloeckl R, Halle M, Kenn K. Interval versus continuous training in lung transplant candidates: a randomized trial. J Heart Lung Transplant 2012;31(9):934-941.

62. Jastrzebski D, Ochman M, Ziora D, Labus L, Kowalski K, Wyrwol $\mathrm{J}$, et al. Pulmonary rehabilitation in patients referred for lung transplantation. In: Pokorski M, editor. Respiratory regulation: clinical advances. Dordrecht: Springer Netherlands, 2013:19-25.

63. Florian J, Rubin A, Mattiello R, Fontoura FF, Camargo Jde J, Teixeira PJZ. Impact of pulmonary rehabilitation on quality of life and functional capacity in patients on waiting lists for lung transplantation. J Bras Pneumol 2013;39(3):349-356. 


\section{Pediatric Lung Transplantation}

64. Li M, Mathur S, Chowdhury NA, Helm D, Singer LG. Pulmonary rehabilitation in lung transplant candidates. J Heart Lung Transplant 2013;32(6):626-632.

65. Baruteau AE, Serraf A, Lévy M, Petit J, Bonnet D, Jais X, et al. Potts shunt in children with idiopathic pulmonary arterial hypertension: long-term results. Ann Thorac Surg 2012;94(3):817-824.

66. Lammers AE, Haworth SG, Diller GP. Atrial septostomy in patients with pulmonary hypertension: should it be recommended? Expert Rev Respir Med 2011;5(3):363-376.

67. Vece TJ, Fan LL. Diagnosis and management of diffuse lung disease in children. Paediatr Respir Rev 2011;12(4):238-242.

68. Yusen RD, Edwards LB, Kucheryavaya AY, Benden C, Dipchand AI, Goldfarb SB, et al. The Registry of the International Society for Heart and Lung Transplantation: thirty-second official adult lung and heart-lung transplantation report-2015; focus theme: early graft failure. J Heart Lung Transplant 2015;34(10):1264-1277.

69. Elizur A, Faro A, Huddleston CB, Gandhi SK, White D, Kuklinski CA, Sweet SC. Lung transplantation in infants and toddlers from 1990 to 2004 at St. Louis Children's Hospital. Am J Transplant 2009;9(4):719-726.

70. Turner DA, Cheifetz IM, Rehder KJ, Williford WL, Bonadonna D, Banuelos SJ, et al. Active rehabilitation and physical therapy during extracorporeal membrane oxygenation while awaiting lung transplantation: a practical approach. Crit Care Med 2011;39(12):2593-2598.

71. Schmidt F, Sasse M, Boehne M, Mueller C, Bertram H, Kuehn C, et al. Concept of "awake venovenous extracorporeal membrane oxygenation" in pediatric patients awaiting lung transplantation. Pediatr Transplant 2013;17(3):224-230.

72. Hayes D Jr, Kukreja J, Tobias JD, Ballard HO, Hoopes CW. Ambulatory venovenous extracorporeal respiratory support as a bridge for cystic fibrosis patients to emergent lung transplantation. J Cyst Fibros 2012;11(1):40-45.

73. de Perrot M, Granton JT, McRae K, Cypel M, Pierre A, Waddell TK, et al. Impact of extracorporeal life support on outcome in patients with idiopathic pulmonary arterial hypertension awaiting lung transplantation. J Heart Lung Transplant 2011;30(9):997-1002.

74. Gazit AZ, Sweet SC, Grady RM, Huddleston CB. First experience with a paracorporeal artificial lung in a small child with pulmonary hypertension. J Thorac Cardiovasc Surg 2011;141(6):e48-e50.

75. Rehder KJ, Turner DA, Hartwig MG, Williford WL, Bonadonna D, Walczak RJ Jr, et al. Active rehabilitation during extracorporeal membrane oxygenation as a bridge to lung transplantation. Respir Care 2013;58(8):1291-1298.

76. Inci I, Klinzing S, Schneiter D, Schuepbach RA, Kestenholz P, Hillinger $\mathrm{S}$, et al. Outcome of extracorporeal membrane oxygenation as a bridge to lung transplantation: an institutional experience and literature review. Transplantation 2015;99(8):1667-1671.

77. Orens JB, Boehler A, de Perrot M, Estenne M, Glanville AR, Keshavjee $\mathrm{S}$, et al. A review of lung transplant donor acceptability criteria. J Heart Lung Transplant 2003;22(11):1183-1200.

78. Cypel M, Yeung JC, Liu M, Anraku M, Chen F, Karolak W, et al. Normothermic ex vivo lung perfusion in clinical lung transplantation. N Engl J Med 2011;364(15):1431-1440.

79. Huddleston CB. Airway complications in children following lung transplantation. In: Cooper DKC, Miller LW, Patterson GA, editors. The Transplantation and Replacement of Thoracic Organs. Dordrecht: Springer Netherlands; 1996:581-588.

80. Huddleston CB. Pediatric lung transplantation. Semin Pediatr Surg 2006;15(3):199-207.

81. Pasque MK, Cooper JD, Kaiser LR, Haydock DA, Triantafillou A, Trulock EP. Improved technique for bilateral lung transplantation: rationale and initial clinical experience. Ann Thorac Surg 1990; 49(5):785-791.
82. Starnes VA, Barr ML, Cohen RG. Lobar transplantation: indications, technique, and outcome. J Thorac Cardiovasc Surg 1994;108(3):403410; discussion 410-411.

83. Date H, Sato M, Aoyama A, Yamada T, Mizota T, Kinoshita H, et al. Living-donor lobar lung transplantation provides similar survival to cadaveric lung transplantation even for very ill patients. Eur J Cardiothorac Surg 2015;47(6):967-972; discussion 972-963.

84. Benden C, Inci I, Weder W, Boehler A. Size-reduced lung transplantation in children-an option worth to consider! Pediatr Transplant 2010;14(4):529-533.

85. Mendeloff EN. Pediatric lung transplantation. Chest Surg Clin N Am 2003;13(3):485-504.

86. Neoh CF, Snell GI, Kotsimbos T, Levvey B, Morrissey CO, Slavin $\mathrm{MA}$, et al. Antifungal prophylaxis in lung transplantation: a worldwide survey. Am J Transplant 2011;11(2):361-366.

87. Langer D, Burtin C, Schepers L, Ivanova A, Verleden G, Decramer $\mathrm{M}$, et al. Exercise training after lung transplantation improves participation in daily activity: a randomized controlled trial. Am J Transplant 2012;12(6):1584-1592.

88. Mitchell MJ, Baz MA, Fulton MN, Lisor CF, Braith RW. Resistance training prevents vertebral osteoporosis in lung transplant recipients. Transplantation 2003;76(3):557-562.

89. Deliva RD, Hassall A, Manlhiot C, Solomon M, McCrindle BW, Dipchand AI. Effects of an acute, outpatient physiotherapy exercise program following pediatric heart or lung transplantation. Pediatr Transplant 2012;16(8):879-886.

90. Benden C, Edwards LB, Kucheryavaya AY, Christie JD, Dipchand AI, Dobbels F, et al. The Registry of the International Society for Heart and Lung Transplantation: fifteenth pediatric lung and heartlung transplantation report-2012. J Heart Lung Transplant 2012; 31(10):1087-1095.

91. Benden C, Aurora P, Edwards LB, Kucheryavaya AY, Christie JD, Dobbels F, et al. The Registry of the International Society for Heart and Lung Transplantation: fourteenth pediatric lung and heart-lung transplantation report-2011. J Heart Lung Transplant 2011;30(10):11231132 .

92. Scully BB, Zafar F, Schecter MG, Rossano JW, Mallory GB Jr, Heinle JS, Morales DL. Lung retransplantation in children: appropriate when selectively applied. Ann Thorac Surg 2011;91(2):574-579.

93. Sweet SC, Wong HH, Webber SA, Horslen S, Guidinger MK, Fine RN, et al. Pediatric transplantation in the United States, 1995-2004. Am J Transplant 2006(5 Pt 2);6:1132-1152.

94. Ringewald JM, Gidding SS, Crawford SE, Backer CL, Mavroudis C, Pahl E. Nonadherence is associated with late rejection in pediatric heart transplant recipients. J Pediatr 2001;139(1):75-78.

95. Gaston RS. Maintenance immunosuppression in the renal transplant recipient: an overview. Am J Kidney Dis 2001;38(6 Suppl 6):S25-S35.

96. Annunziato RA, Emre S, Shneider B, Barton C, Dugan CA, Shemesh E. Adherence and medical outcomes in pediatric liver transplant recipients who transition to adult services. Pediatr Transplant 2007; 11(6):608-614.

97. Reiss JG, Gibson RW, Walker LR. Health care transition: youth, family, and provider perspectives. Pediatrics 2005;115(1):112-120.

98. Stabile L, Rosser L, Porterfield KM, McCauley S, Levenson C, Haglund J, Christman K. Transfer versus transition: success in pediatric transplantation brings the welcome challenge of transition. Prog Transplant 2005;15(4):363-370.

99. McDonagh JE, Kelly DA. The challenges and opportunities for transitional care research. Pediatr Transplant 2010;14(6):688-700.

100. Bell LE, Bartosh SM, Davis CL, Dobbels F, Al-Uzri A, Lotstein D, et al. Adolescent transition to adult care in solid organ transplantation: a consensus conference report. Am J Transplant 2008;8(11): 2230-2242. 


\section{Pediatric Lung Transplantation}

101. Trulock EP. Management of lung transplant rejection. Chest 1993; 103(5):1566-1576

102. Sweet SC. Pediatric lung transplantation: update 2003. Pediatr Clin North Am 2003;50(6):1393-1417, ix.

103. Schulman LL, Anandarangam T, Leibowitz DW, Ditullio MR, McGregor CC, Galantowicz ME, Homma S. Four-year prospective study of pulmonary venous thrombosis after lung transplantation. J Am Soc Echocardiogr 2001;14(8):806-812.

104. Toronto Lung Transplant Group. Unilateral lung transplantation for pulmonary fibrosis. N Eng1 J Med 1986;314(18):1140-1145.

105. Mendeloff EN. Donor selection, organ preservation, surgical technique and perioperative management. In: Tejani AH, Harmon WE, Fine RN, editors. Pediatric solid organ transplantation. Copenhagen, Denmark: Munksgaard, 2000:471-481.

106. Grauhan O, Knosalla C, Ewert R, Hummel M, Loebe M, Weng YG, Hetzer R. Plasmapheresis and cyclophosphamide in the treatment of humoral rejection after heart transplantation. J Heart Lung Transplant 2001;20(3):316-321.

107. Christie JD, Van Raemdonck D, de Perrot M, Barr M, Keshavjee S, Arcasoy S, et al. Report of the ISHLT Working Group on Primary Lung Graft Dysfunction part I: introduction and methods. J Heart Lung Transplant 2005;24(10):1451-1453.

108. Christie JD, Carby M, Bag R, Corris P, Hertz M, Weill D, ISHLT Working Group on Primary Lung Graft Dysfunction. Report of the ISHLT Working Group on Primary Lung Graft Dysfunction part II: definition: a consensus statement of the International Society for Heart and Lung Transplantation. J Heart Lung Transplant 2005; 24(10):1454-1459.

109. de Perrot M, Bonser RS, Dark J, Kelly RF, McGiffin D, Menza R, et al. Report of the ISHLT Working Group on Primary Lung Graft Dysfunction part III: donor-related risk factors and markers. J Heart Lung Transplant 2005;24(10):1460-1467.

110. Barr ML, Kawut SM, Whelan TP, Girgis R, Böttcher H, Sonett J, et al. Report of the ISHLT Working Group on Primary Lung Graft Dysfunction part IV: recipient-related risk factors and markers. J Heart Lung Transplant 2005;24(10):1468-1482.

111. Arcasoy SM, Fisher A, Hachem RR, Scavuzzo M, Ware LB, ISHLT Working Group on Primary Lung Graft Dysfunction. Report of the ISHLT Working Group on Primary Lung Graft Dysfunction part V: predictors and outcomes. J Heart Lung Transplant 2005;24(10):14831488 .

112. Shargall Y, Guenther G, Ahya VN, Ardehali A, Singhal A, Keshavjee S, ISHLT Working Group on Primary Lung Graft Dysfunction. Report of the ISHLT Working Group on Primary Lung Graft Dysfunction part VI: treatment. J Heart Lung Transplant 2005; 24(10):1489-1500

113. Nguyen DQ, Kulick DM, Bolman RM 3rd, Dunitz JM, Hertz MI, Park SJ. Temporary ECMO support following lung and heart-lung transplantation. J Heart Lung Transplant 2000;19(3):313-316.

114. Meyers BF, Sundt TM 3rd, Henry S, Trulock EP, Guthrie T, Cooper JD, Patterson GA. Selective use of extracorporeal membrane oxygenation is warranted after lung transplantation. J Thorac Cardiovasc Surg 2000;120(1):20-26.

115. Novick RJ, Stitt LW, Al-Kattan K, Klepetko W, Schäfers HJ, Duchatelle JP, et al. Pulmonary retransplantation: predictors of graft function and survival in 230 patients: Pulmonary Retransplant Registry. Ann Thorac Surg 1998;65(1):227-234

116. Ibrahim JE, Sweet SC, Flippin M, Dent C, Mendelhoff E, Huddleston $\mathrm{CB}$, et al. Rejection is reduced in thoracic organ recipients when transplanted in the first year of life. J Heart Lung Transplant 2002;21(3):311-318

117. Berry GJ, Brunt EM, Chamberlain D, Hruban RH, Sibley RK, Stewart S, Tazelaar HD. A working formulation for the standardization of nomenclature in the diagnosis of heart and lung rejection:
Lung Rejection Study Group: The International Society for Heart Transplantation. J Heart Transplant 1990;9(6):593-601.

118. Yousem SA, Berry GJ, Cagle PT, Chamberlain D, Husain AN, Hruban RH, et al. Revision of the 1990 working formulation for the classification of pulmonary allograft rejection: Lung Rejection Study Group. J Heart Lung Transplant 1996;15(1 Pt 1):1-15.

119. Stewart S, Fishbein MC, Snell GI, Berry GJ, Boehler A, Burke MM, et al. Revision of the 1996 working formulation for the standardization of nomenclature in the diagnosis of lung rejection. J Heart Lung Transplant 2007;26(12):1229-1242.

120. Hopkins PM, Aboyoun CL, Chhajed PN, Malouf MA, Plit ML, Rainer SP, Glanville AR. Association of minimal rejection in lung transplant recipients with obliterative bronchiolitis. Am J Respir Crit Care Med 2004;170(9):1022-1026.

121. Hachem RR, Khalifah AP, Chakinala MM, Yusen RD, Aloush AA, Mohanakumar T, et al. The significance of a single episode of minimal acute rejection after lung transplantation. Transplantation 2005;80(10):1406-1413.

122. Benden C, Faro A, Worley S, Arrigain S, Aurora P, Ballmann M, et al. Minimal acute rejection in pediatric lung transplantation: does it matter? Pediatr Transplant 2010;14(4):534-539.

123. Takemoto SK, Zeevi A, Feng S, Colvin RB, Jordan S, Kobashigawa $\mathrm{J}$, et al. National conference to assess antibody-mediated rejection in solid organ transplantation. Am J Transplant 2004;4(7): 1033-1041.

124. Berry G, Burke M, Andersen C, Angelini A, Bruneval P, Calabrese F, et al. Pathology of pulmonary antibody-mediated rejection: 2012 update from the Pathology Council of the ISHLT. J Heart Lung Transplant 2013;32(1):14-21.

125. Martinu T, Chen DF, Palmer SM. Acute rejection and humoral sensitization in lung transplant recipients. Proc Am Thorac Soc 2009;6(1):54-65.

126. Everly MJ. A summary of bortezomib use in transplantation across 29 centers. Clin Transpl 2009;323-337.

127. Stegall MD, Gloor JM. Deciphering antibody-mediated rejection: new insights into mechanisms and treatment. Curr Opin Organ Transplant 2010;15(1):8-10.

128. Pettersson GB, Karam K, Thuita L, Johnston DR, McCurry KR, Kapadia SR, et al. Comparative study of bronchial artery revascularization in lung transplantation. J Thorac Cardiovasc Surg 2013; 146(4):894-900.e3.

129. Kaditis AG, Gondor M, Nixon PA, Webber S, Keenan RJ, Kaye R, Kurland G. Airway complications following pediatric lung and heartlung transplantation. Am J Respir Crit Care Med 2000;162(1):301309.

130. Choong CK, Sweet SC, Zoole JB, Guthrie TJ, Mendeloff EN, Haddad FJ, et al. Bronchial airway anastomotic complications after pediatric lung transplantation: incidence, cause, management, and outcome. J Thorac Cardiovasc Surg 2006;131(1):198-203.

131. Vinograd I, Keidar S, Weinberg M, Silbiger A. Treatment of airway obstruction by metallic stents in infants and children. J Thorac Cardiovasc Surg 2005;130(1):146-150.

132. Vondrys D, Elliott MJ, McLaren CA, Noctor C, Roebuck DJ. First experience with biodegradable airway stents in children. Ann Thorac Surg 2011;92(5):1870-1874.

133. Duarte AG, Myers AC. Cough reflex in lung transplant recipients. Lung 2012;190(1):23-27.

134. Herve P, Silbert D, Cerrina J, Simonneau G, Dartevelle P. Impairment of bronchial mucociliary clearance in long-term survivors of heart/lung and double-lung transplantation: the Paris-Sud lung transplant group. Chest 1993;103(1):59-63.

135. Read RC, Shankar S, Rutman A, Feldman C, Yacoub M, Cole PJ, Wilson R. Ciliary beat frequency and structure of recipient and 


\section{Pediatric Lung Transplantation}

donor epithelia following lung transplantation. Eur Respir J 1991; 4(7):796-801.

136. Veale D, Glasper PN, Gascoigne A, Dark JH, Gibson GJ, Corris PA. Ciliary beat frequency in transplanted lungs. Thorax 1993; 48(6):629-631.

137. Laube BL, Karmazyn YJ, Orens JB, Mogayzel PJ Jr. Albuterol improves impaired mucociliary clearance after lung transplantation. J Heart Lung Transplant 2007;26(2):138-144.

138. Alexander BD, Tapson VF. Infectious complications of lung transplantation. Transpl Infect Dis 2001;3(3):128-137.

139. Lewiston N, King V, Umetsu D, Starnes V, Marshall S, Kramer M, Theodore J. Cystic fibrosis patients who have undergone heart-lung transplantation benefit from maxillary sinus antrostomy and repeated sinus lavage. Transplant Proc 1991;23(1 Pt 2):1207-1208.

140. Holzmann D, Speich R, Kaufmann T, Laube I, Russi EW, Simmen $\mathrm{D}$, et al. Effects of sinus surgery in patients with cystic fibrosis after lung transplantation: a 10-year experience. Transplantation 2004; 77(1):134-136.

141. Leung MK, Rachakonda L, Weill D, Hwang PH. Effects of sinus surgery on lung transplantation outcomes in cystic fibrosis. Am J Rhinol 2008;22(2):192-196.

142. Smyth RL, Scott JP, Borysiewicz LK, Sharples LD, Stewart S, Wreghitt TG, et al. Cytomegalovirus infection in heart-lung transplant recipients: risk factors, clinical associations, and response to treatment. J Infect Dis 1991;164(6):1045-1050.

143. Soghikian MV, Valentine VG, Berry GJ, Patel HR, Robbins RC, Theodore J. Impact of ganciclovir prophylaxis on heart-lung and lung transplant recipients. J Heart Lung Transplant 1996;15(9):881-887.

144. Tamm M, Aboyoun CL, Chhajed PN, Rainer S, Malouf MA, Glanville AR. Treated cytomegalovirus pneumonia is not associated with bronchiolitis obliterans syndrome. Am J Respir Crit Care Med 2004;170(10):1120-1123.

145. Bridges ND, Spray TL, Collins MH, Bowles NE, Towbin JA. Adenovirus infection in the lung results in graft failure after lung transplantation. J Thorac Cardiovasc Surg 1998;116(4):617-623.

146. Wendt CH, Fox JM, Hertz MI. Paramyxovirus infection in lung transplant recipients. J Heart Lung Transplant 1995;14(3):479-485.

147. McCurdy LH, Milstone A, Dummer S. Clinical features and outcomes of paramyxoviral infection in lung transplant recipients treated with ribavirin. J Heart Lung Transplant 2003;22(7):745-753.

148. Khalifah AP, Hachem RR, Chakinala MM, Schechtman KB, Patterson GA, Schuster DP, et al. Respiratory viral infections are a distinct risk for bronchiolitis obliterans syndrome and death. Am J Respir Crit Care Med 2004;170(2):181-187.

149. Doan ML, Mallory GB, Kaplan SL, Dishop MK, Schecter MG, McKenzie ED, et al. Treatment of adenovirus pneumonia with cidofovir in pediatric lung transplant recipients. J Heart Lung Transplant 2007;26(9):883-889.

150. Glanville AR, Scott AI, Morton JM, Aboyoun CL, Plit ML, Carter IW, Malouf MA. Intravenous ribavirin is a safe and cost-effective treatment for respiratory syncytial virus infection after lung transplantation. J Heart Lung Transplant 2005;24(12):2114-2119.

151. Danziger-Isakov LA, Worley S, Arrigain S, Aurora P, Ballmann M, Boyer D, et al. Increased mortality after pulmonary fungal infection within the first year after pediatric lung transplantation. J Heart Lung Transplant 2008;27(6):655-661.

152. Knoll BM, Kappagoda S, Gill RR, Goldberg HJ, Boyle K, Baden LR, et al. Non-tuberculous mycobacterial infection among lung transplant recipients: a 15 -year cohort study. Transpl Infect Dis 2012;14(5):452-460.

153. Singh N, Singh NM, Husain S, AST Infectious Diseases Community of Practice. Aspergillosis in solid organ transplantation. Am J Transplant 2013(Suppl 4);13:228-241.
154. Lubetkin EI, Lipson DA, Palevsky HI, Kotloff R, Morris J, Berry GT, et al. GI complications after orthotopic lung transplantation. Am J Gastroenterol 1996;91(11):2382-2390.

155. Gandhi SK, Bromberg BI, Mallory GB, Huddleston CB. Atrial flutter: a newly recognized complication of pediatric lung transplantation. J Thorac Cardiovasc Surg 1996;112(4):984-991.

156. Armitage JM, Fricker FJ, del Nido P, Starzl TE, Hardesty RL, Griffith BP. A decade (1982 to 1992) of pediatric cardiac transplantation and the impact of FK 506 immunosuppression. J Thorac Cardiovasc Surg 1993;105(3):464-472; discussion 472-473.

157. Wong M, Mallory GB Jr, Goldstein J, Goyal M, Yamada KA. Neurologic complications of pediatric lung transplantation. Neurology 1999;53(7):1542-1549.

158. Bartynski WS, Tan HP, Boardman JF, Shapiro R, Marsh JW. Posterior reversible encephalopathy syndrome after solid organ transplantation. AJNR Am J Neuroradiol 2008;29(5):924-930.

159. Fan Y, Xiao YB, Weng YG. Tacrolimus versus cyclosporine for adult lung transplant recipients: a meta-analysis. Transplant Proc 2009;41(5):1821-1824.

160. Purtilo DT, Strobach RS, Okano M, Davis JR. Epstein-Barr virusassociated lymphoproliferative disorders. Lab Invest 1992;67(1):5-23.

161. Boyle GJ, Michaels MG, Webber SA, Knisely AS, Kurland G, Cipriani LA, et al. Posttransplantation lymphoproliferative disorders in pediatric thoracic organ recipients. J Pediatr 1997;131(2):309-313.

162. Bakker NA, van Imhoff GW, Verschuuren EA, van Son WJ, Homan van der Heide JJ, Veeger NJ, et al. Early onset post-transplant lymphoproliferative disease is associated with allograft localization. Clin Transplant 2005;19(3):327-334.

163. Lim GY, Newman B, Kurland G, Webber SA. Posttransplantation lymphoproliferative disorder: manifestations in pediatric thoracic organ recipients. Radiology 2002;222(3):699-708.

164. Herrmann BW, Sweet SC, Molter DW. Sinonasal posttransplant lymphoproliferative disorder in pediatric lung transplant patients. Otolaryngol Head Neck Surg 2005;133(1):38-41.

165. Herrmann BW, Sweet SC, Hayashi RJ, Canter CE, White FV, Lieu JE. Otolaryngological manifestations of posttransplant lymphoproliferative disorder in pediatric thoracic transplant patients. Int J Pediatr Otorhinolaryngol 2006;70(2):303-310.

166. Wheless SA, Gulley ML, Raab-Traub N, McNeillie P, Neuringer IP, Ford HJ, Aris RM. Post-transplantation lymphoproliferative disease: Epstein-Barr virus DNA levels, HLA-A3, and survival. Am J Respir Crit Care Med 2008;178(10):1060-1065.

167. Bakker NA, Verschuuren EA, Erasmus ME, Hepkema BG, Veeger NJ, Kallenberg CG, van der Bij W. Epstein-Barr virus-DNA load monitoring late after lung transplantation: a surrogate marker of the degree of immunosuppression and a safe guide to reduce immunosuppression. Transplantation 2007;83(4):433-438.

168. Benden C, Aurora P, Burch M, Cubitt D, Lloyd C, Whitmore P, et al. Monitoring of Epstein-Barr viral load in pediatric heart and lung transplant recipients by real-time polymerase chain reaction. J Heart Lung Transplant 2005;24(12):2103-2108.

169. Blaes AH, Cioc AM, Froelich JW, Peterson BA, Dunitz JM. Positron emission tomography scanning in the setting of post-transplant lymphoproliferative disorders. Clin Transplant 2009;23(6):794-799.

170. Chadburn A, Chen JM, Hsu DT, Frizzera G, Cesarman E, Garrett TJ, et al. The morphologic and molecular genetic categories of posttransplantation lymphoproliferative disorders are clinically relevant. Cancer 1998;82(10):1978-1987.

171. Gupta S, Fricker FJ, González-Peralta RP, Slayton WB, Schuler PM, Dharnidharka VR. Post-transplant lymphoproliferative disorder in children: recent outcomes and response to dual rituximab/low-dose chemotherapy combination. Pediatr Transplant 2010;14(7):896-902.

172. Valapour M, Skeans MA, Smith JM, Edwards LB, Cherikh WS, Callahan ER, et al. Lung. Am J Transplant 2016(Suppl 2);16:141-168. 


\section{Pediatric Lung Transplantation}

173. Colvin M, Smith JM, Skeans MA, Edwards LB, Callahan ER, Snyder JJ, et al. Heart. Am J Transplant 2016(Suppl 2);16:115-140.

174. Kim WR, Lake JR, Smith JM, Skeans MA, Schladt DP, Edwards EB, et al. Liver. Am J Transplant 2016(Suppl 2);16:69-98.

175. Hart A, Smith JM, Skeans MA, Gustafson SK, Stewart DE, Cherikh WS, et al. Kidney. Am J Transplant 2016;16(Suppl 2):11-46.

176. Cooper JD, Billingham M, Egan T, Hertz MI, Higenbottam T, Lynch $\mathrm{J}$, et al. A working formulation for the standardization of nomenclature and for clinical staging of chronic dysfunction in lung allografts. J Heart Lung Transplant 1993;12(5):713-716.

177. Estenne M, Maurer JR, Boehler A, Egan JJ, Frost A, Hertz M, et al. Bronchiolitis obliterans syndrome 2001: an update of the diagnostic criteria. J Heart Lung Transplant 2002;21(3):297-310.

178. Burke CM, Theodore J, Dawkins KD, Yousem SA, Blank N, Billingham ME, et al. Post-transplant obliterative bronchiolitis and other late lung sequelae in human heart-lung transplantation. Chest 1984; 86(6):824-829.

179. Leung AN, Fisher K, Valentine V, Girgis RE, Berry GJ, Robbins $\mathrm{RC}$, Theodore J. Bronchiolitis obliterans after lung transplantation: detection using expiratory HRCT. Chest 1998;113(2):365-370.

180. Halvorsen RA Jr, DuCret RP, Kuni CC, Olivari MT, Tylen U, Hertz MI. Obliterative bronchiolitis following lung transplantation: diagnostic utility of aerosol ventilation lung scanning and high resolution CT. Clin Nucl Med 1991;16(4):256-258.

181. Verleden GM, Raghu G, Meyer KC, Glanville AR, Corris P. A new classification system for chronic lung allograft dysfunction. J Heart Lung Transplant 2014;33(2):127-133.

182. Corris PA, Ryan VA, Small T, Lordan J, Fisher AJ, Meachery G, et al. A randomised controlled trial of azithromycin therapy in bronchiolitis obliterans syndrome (BOS) post lung transplantation. Thorax 2015;70(5):442-450.

183. Sato M, Waddell TK, Wagnetz U, Roberts HC, Hwang DM, Haroon A, et al. Restrictive allograft syndrome (RAS): a novel form of chronic lung allograft dysfunction. J Heart Lung Transplant 2011; 30(7):735-742.

184. Verleden SE, de Jong PA, Ruttens D, Vandermeulen E, van Raemdonck DE, Verschakelen J, et al. Functional and computed tomographic evolution and survival of restrictive allograft syndrome after lung transplantation. J Heart Lung Transplant 2014; 33(3):270-277.

185. Sharples LD, McNeil K, Stewart S, Wallwork J. Risk factors for bronchiolitis obliterans: a systematic review of recent publications. J Heart Lung Transplant 2002;21(2):271-281.

186. Jaramillo A, Smith MA, Phelan D, Sundaresan S, Trulock EP, Lynch JP, et al. Development of ELISA-detected anti-HLA antibodies precedes the development of bronchiolitis obliterans syndrome and correlates with progressive decline in pulmonary function after lung transplantation. Transplantation 1999;67(8):1155-1161.

187. Palmer SM, Davis RD, Hadjiliadis D, Hertz MI, Howell DN, Ward FE, et al. Development of an antibody specific to major histocompatibility antigens detectable by flow cytometry after lung transplant is associated with bronchiolitis obliterans syndrome. Transplantation 2002;74(6):799-804.

188. Goers TA, Ramachandran S, Aloush A, Trulock E, Patterson GA, Mohanakumar T. De novo production of K- $\alpha 1$ tubulin-specific antibodies: role in chronic lung allograft rejection. J Immunol 2008; 180(7):4487-4494.

189. Sumpter TL, Wilkes DS. Role of autoimmunity in organ allograft rejection: a focus on immunity to type $\mathrm{V}$ collagen in the pathogenesis of lung transplant rejection. Am J Physiol Lung Cell Mol Physiol 2004;286(6):L1129-L1139.

190. Brugière O, Thabut G, Krawice-Radanne I, Rizzo R, Dauriat G, Danel C, et al. Role of HLA-G as a predictive marker of low risk of chronic rejection in lung transplant recipients: a clinical prospective study. Am J Transplant 2015;15(2):461-471.

191. White SR, Floreth T, Liao C, Bhorade SM. Association of soluble HLA-G with acute rejection episodes and early development of bronchiolitis obliterans in lung transplantation. PLoS One 2014;9(7):e103643.

192. D'Ovidio F, Keshavjee S. Gastroesophageal reflux and lung transplantation. Dis Esophagus 2006;19(5):315-320.

193. Davis RD Jr, Lau CL, Eubanks S, Messier RH, Hadjiliadis D, Steele MP, Palmer SM. Improved lung allograft function after fundoplication in patients with gastroesophageal reflux disease undergoing lung transplantation. J Thorac Cardiovasc Surg 2003;125(3):533-542.

194. Kumar D, Husain S, Chen MH, Moussa G, Himsworth D, Manuel O, et al. A prospective molecular surveillance study evaluating the clinical impact of community-acquired respiratory viruses in lung transplant recipients. Transplantation 2010;89(8):1028-1033.

195. Gottlieb J, Schulz TF, Welte T, Fuehner T, Dierich M, Simon AR, Engelmann I. Community-acquired respiratory viral infections in lung transplant recipients: a single season cohort study. Transplantation 2009;87(10):1530-1537.

196. Verleden SE, Ruttens D, Vandermeulen E, Bellon H, Van Raemdonck DE, Dupont LJ, et al. Restrictive chronic lung allograft dysfunction: where are we now? J Heart Lung Transplant 2015; 34(5):625-630.

197. Paraskeva M, McLean C, Ellis S, Bailey M, Williams T, Levvey B, et al. Acute fibrinoid organizing pneumonia after lung transplantation. Am J Respir Crit Care Med 2013;187(12):1360-1368.

198. Otto C, Huzly D, Kemna L, Hüttel A, Benk C, Rieg S, et al. Acute fibrinous and organizing pneumonia associated with influenza A/H1N1 pneumonia after lung transplantation. BMC Pulm Med 2013;13:30.

199. Vos R, Verleden SE, Verleden GM. Chronic lung allograft dysfunction: evolving practice. Curr Opin Organ Transplant 2015;20(5):483491.

200. Woo MS, MacLaughlin EF, Horn MV, Szmuszkovicz JR, Barr ML, Starnes VA. Bronchiolitis obliterans is not the primary cause of death in pediatric living donor lobar lung transplant recipients. J Heart Lung Transplant 2001;20(5):491-496.

201. Sweet SC. Pediatric living donor lobar lung transplantation. Pediatr Transplant 2006;10(7):861-868.

202. Boehler A, Kesten S, Weder W, Speich R. Bronchiolitis obliterans after lung transplantation: a review. Chest 1998;114(5):1411-1426.

203. Vanaudenaerde BM, De Vleeschauwer SI, Vos R, Meyts I, Bullens DM, Reynders V, et al. The role of the IL23/IL17 axis in bronchiolitis obliterans syndrome after lung transplantation. Am J Transplant 2008;8(9):1911-1920.

204. Vos R, Verleden SE, Ruttens D, Vandermeulen E, Bellon H, Neyrinck $\mathrm{A}$, et al. Azithromycin and the treatment of lymphocytic airway inflammation after lung transplantation. Am J Transplant 2014;14(12):2736-2748.

205. Ruttens D, Wauters E, Kiciński M, Verleden SE, Vandermeulen E, Vos R, et al. Genetic variation in interleukin-17 receptor A is functionally associated with chronic rejection after lung transplantation. J Heart Lung Transplant 2013;32(12):1233-1240.

206. Aramini B, Kim C, Diangelo S, Petersen E, Lederer DJ, Shah L, et al. Donor surfactant protein D (SP-D) polymorphisms are associated with lung transplant outcome. Am J Transplant 2013;13(8):2130-2136.

207. Bourdin A, Mifsud NA, Chanez B, McLean C, Chanez P, Snell G, Kotsimbos TC. Donor clara cell secretory protein polymorphism is a risk factor for bronchiolitis obliterans syndrome after lung transplantation. Transplantation 2012;94(6):652-658.

208. Kastelijn EA, van Moorsel CHM, Ruven HJT, Lammers JWJ, Grutters JC. Genetic polymorphisms and bronchiolitis obliterans syndrome after lung transplantation: promising results and recommendations for the future. Transplantation 2012;93(2):127-135. 
209. Verleden SE, Ruttens D, Vos R, Vandermeulen E, Moelants E, Mortier A, et al. Differential cytokine, chemokine and growth factor expression in phenotypes of chronic lung allograft dysfunction. Transplantation 2015;99(1):86-93.

210. Saito T, Liu M, Binnie M, Sato M, Hwang D, Azad S, et al. Distinct expression patterns of alveolar "alarmins" in subtypes of chronic lung allograft dysfunction. Am J Transplant 2014;14(6):1425-1432.

211. Suwara MI, Vanaudenaerde BM, Verleden SE, Vos R, Green NJ, Ward C, et al. Mechanistic differences between phenotypes of chronic lung allograft dysfunction after lung transplantation. Transplant Int 2014;27(8):857-867.

212. Kastelijn EA, van Moorsel CH, Ruven HJ, Korthagen NM, Kwakkel-van Erp JM, van de Graaf EA, et al. YKL-40 and matrix metalloproteinases as potential biomarkers of inflammation and fibrosis in the development of bronchiolitis obliterans syndrome. Sarcoidosis Vasc Diffuse Lung Dis 2013;30(1):28-35.

213. Tiriveedhi V, Banan B, Deepti S, Nataraju A, Hachem R, Trulock $\mathrm{E}$, et al. Role of defensins in the pathogenesis of chronic lung allograft rejection. Human Immunology 2014;75(4):370-377.

214. El-Gamel A, Sim E, Hasleton P, Hutchinson J, Yonan N, Egan J, et al. Transforming growth factor $\beta$ (TGF- $\beta$ ) and obliterative bronchiolitis following pulmonary transplantation. J Heart Lung Transplant 1999;18(9):828-837.

215. Hertz MI, Henke CA, Nakhleh RE, Harmon KR, Marinelli WA, Fox JM, et al. Obliterative bronchiolitis after lung transplantation: a fibroproliferative disorder associated with platelet-derived growth factor. Proc Natl Acad Sci USA 1992;89(21):10385-10389.

216. Verleden GM, Vanaudenaerde BM, Dupont LJ, Van Raemdonck DE. Azithromycin reduces airway neutrophilia and interleukin-8 in patients with bronchiolitis obliterans syndrome. Am J Respir Crit Care Med 2006;174(5):566-570.

217. Roman A, Bravo C, Monforte V, Reyes L, Canela M, Morell F. Preliminary results of rescue therapy with tacrolimus and mycophenolate mofetil in lung transplanted patients with bronchiolitis obliterans. Transplant Proc 2002;34(1):146-147.

218. Date H, Lynch JP, Sundaresan S, Patterson GA, Trulock EP. The impact of cytolytic therapy on bronchiolitis obliterans syndrome. J Heart Lung Transplant 1998;17(9):869-875.

219. Verleden GM, Buyse B, Delcroix M, Fabri R, Vanhaecke J, Van Raemdonck D, et al. Cyclophosphamide rescue therapy for chronic rejection after lung transplantation. J Heart Lung Transplant 1999; 18(11):1139-1142.

220. Dusmet M, Maurer J, Winton T, Kesten S. Methotrexate can halt the progression of bronchiolitis obliterans syndrome in lung transplant recipients. J Heart Lung Transplant 1996;15(9):948-954.

221. Diamond DA, Michalski JM, Lynch JP, Trulock EP 3rd. Efficacy of total lymphoid irradiation for chronic allograft rejection following bilateral lung transplantation. Int J Radiat Oncol Biol Phys 1998;41(4):795-800.

222. O'Hagan AR, Stillwell PC, Arroliga A, Koo A. Photopheresis in the treatment of refractory bronchiolitis obliterans complicating lung transplantation. Chest 1999;115(5):1459-1462.

223. Morrell MR, Despotis GJ, Lublin DM, Patterson GA, Trulock EP, Hachem RR. The efficacy of photopheresis for bronchiolitis obliterans syndrome after lung transplantation. J Heart Lung Transplant 2010;29(4):424-431.

224. Benden C, Speich R, Hofbauer GF, Irani S, Eich-Wanger C, Russi EW, et al. Extracorporeal photopheresis after lung transplantation: a 10-year single-center experience. Transplantation 2008;86(11):16251627.

225. Yung GL, Craig V. Lung transplantation and extracorporeal photopheresis: the answer to bronchiolitis obliterans? Transfus Apher Sci 2015;52(2):162-166.

226. Baskaran G, Tiriveedhi V, Ramachandran S, Aloush A, Grossman B, Hachem R, Mohanakumar T. Efficacy of extracorporeal photopheresis in clearance of antibodies to donor-specific and lungspecific antigens in lung transplant recipients. J Heart Lung Transplant 2014;33(9):950-956.

227. Greer M, Dierich M, De Wall C, Suhling H, Rademacher J, Welte $\mathrm{T}$, et al. Phenotyping established chronic lung allograft dysfunction predicts extracorporeal photopheresis response in lung transplant patients. Am J Transplant 2013;13(4):911-918.

228. Jaksch P, Scheed A, Keplinger M, Ernst MB, Dani T, Just U, et al. A prospective interventional study on the use of extracorporeal photopheresis in patients with bronchiolitis obliterans syndrome after lung transplantation. J Heart Lung Transplant 2012;31(9):950-957.

229. Verleden SE, Todd JL, Sato M, Palmer SM, Martinu T, Pavlisko $\mathrm{EN}$, et al. Impact of CLAD phenotype on survival after lung retransplantation: a multicenter study. Am J Transplant 2015;15(8): 2223-2230.

\section{Discussion}

Berlinski: I'll ask you a politically incorrect question. It takes a lot of time to acquire the expertise to do pediatric lung transplants and you know that there are many centers in the country that probably do one lung transplant per year. Wouldn't it make more sense to have a national approach, to zone the country and designate centers of excellence to do a fair number of transplants so the outcomes might be better? This way the distribution of the donor pool might also be improved.

Sweet: Thank you Ariel, that's a really important question. I think the short answer to that question is of course. The data when you look at it really support the concept that experience equals outcome in organ transplantation. But if you take a step back from that and ask the question can it be effective? We don't have the infrastructure yet in place to make it effective across the board. So, in addition to saying "OK we are going to designate a handful of centers regionally that are going to be the expert centers for lung transplantation," then we have to break down the barriers to get patients to those centers. Right now those barriers prevent a subset of the patients who don't have the resources or the psychosocial support system from relocating from their home to these transplant centers to wait the 1,3 , or
6 months for organs and then to stay at the transplant center for upwards of 3 months or longer, depending on how their course goes, before they go back to their home environment. I am a complete advocate of that, but it means we'd have to change our reimbursement approach and our approach of supporting families and children through the pre- and post-transplant period so that we don't create inequity in access by doing it.

Panitch: It seems that you have to take that a step further, because after the transplant, unless everyone sends the patients back to your center for follow-up, you'd have to be able to disseminate expertise for good, close 
follow-up out into the community. Would you comment on that?

Sweet: The model we use for follow-up has been to bring patients back from wherever they are. In our experience, we have transplanted patients in Australia or the Middle East and other places, and the follow-up can be a challenge. We've tried to develop relationships with local providers and local pulmonologists, but we really rely on bringing patients back to our center for reevaluation intermittently: every 3 months in the first year after transplant, every 6 months afterwards. It's a struggle for me to get the patients who are 5 or 6 y out to come back every 6 months, but I think it's important.

Panitch: But if there are issues that occur in the interim, I would assume you'd want someone local who could at least identify and temporize the situation until the patient can get back to the center.

Sweet: Right. In today's world, phones with video instant access can help with that, but you're right, one of the things that's critical for us when we transplant a patient is to identify the local pulmonologist who's going to be our partner in the immediate identification of problems, stratifying issues, and deciding what expertise is available there. We generally don't want the local pulmonologist doing biopsies, not because they're aren't capable of doing it, but because the infrastructure to actually process the biopsies and read them may not be there. So it is a partnership. You're absolutely right, you can't ignore that component of the process.

Stokes: Stuart, that was a great talk. One of the things we struggle with is the timing of when to refer patients, and my philosophy has always been to refer earlier. If somebody goes to see you and you say come back in a year, that's still good, because the family knows how to get to St Louis and has been in to see you, but is that a good use of your time to get those patients early, or do you feel like you are getting patients referred appropriately or too soon? Can you speak to that?

Sweet: That's a great point, Dennis. It's been a bit more challenging, and I didn't talk about the Lung Allocation System, but 10-15 years ago, the allocation of lungs in the United States was strictly based on waiting time. So basically, if you wanted to transplant a pediatric lung transplant candidate, you had to get them at least a year or more before they were ready for transplant, or they were likely to die on the waiting list. You had to accumulate enough time on the list to get organ offers. That has changed. In the Lung Allocation System, now patients 12 y and older can get organs relatively quickly, and that has changed the dynamics of referral a little bit. But I agree with you, having us get to know a patient longer before they actually need to be transplanted allows for assimilation of all the information I just provided to you. The family has to fully understand the implications and the outcomes. It gives them the opportunity to engage in rehabilitation; it gives them the opportunity to address any comorbid factors that are going to play a role in their outcome. I'm a big advocate of seeing patients as soon as transplant comes up in the conversation and it's a serious conversation rather than waiting until it's time to relocate to St Louis, because if you wait that long, you miss the opportunity to address those other things.

Panitch: Sometimes patients with chronic lung diseases don't grow very well, and as they approach late adolescence, we have small patients. When size is a factor, what serves the patient better: to refer to the pediatric lung transplant program or to the adult lung transplant program when they're very small people?
Sweet: I would turn the question around and say what does the patient need? The way the allocation system works doesn't discriminate based on size in that window, in the 18-20-yold patient. You don't lose access dramatically to the adolescent organs; you lose some, but it's not going to be mitigated by being in a pediatric center versus an adult center. Basically, the way the allocation system works is it's not dependent on where you are; it's what your age is. It boils down to what expertise is needed to care for that patient. Ten years ago, I would have said a patient who has chronic lung disease, an 18- or 19-y-old CF patient who's never really been free of their parents and hasn't really developed independence, is probably a bit emotionally behind. And that patient is probably best served in a pediatric center where the care will be a family-centered care model. I would like to think that our adult colleagues, especially our adult CF center colleagues, have begun to recognize the importance of a family-centered approach for patients who aren't fully mature yet. I'd like to think that an adult center would be suitable for them once they hit adulthood, but I think the reality is probably somewhere in between.

Cheifetz: Thank you, Stuart, for a really excellent presentation. I would like to focus on the point of availability of organs for donation and the scarceness of this precious resource. For abdominal organs, one of the approaches, although still somewhat controversial, has been organ donation after cardiac death. Has this approach been considered for lung transplantation? Has it been done? I suspect there are ethical issues and controversies involved, but can you please share your thoughts?

Sweet: The group in Australia has great data ${ }^{1}$ on donation after circulatory death. And actually, the outcomes are good. We have just, for better or 
for worse, in pediatrics not been able to convince our surgeons to go down that path. The data I showed you from Toronto, if you dig into that paper, ${ }^{2} \mathrm{a}$ large number of the organs that they used on their ex vivo lung perfusion circuit were from circulatory death donors. For that there's no ethical barrier, because it's whether the patient is a circulatory death donor, not taking the lungs versus taking the abdominal organs. I completely agree with you, I think it's a huge opportunity for lungs in the United States. I think what we need is the ex vivo lung perfusion technology to become more robust so that people are more comfortable using organs from those donors. The data that are accumulating, particularly in Australia, indicate that with circulatory death donor organs, the outcomes can be as good as or better than with those from brain death. Brain death brings its full set of inflammatory impacts that we probably underrecognize and underappreciate.

Walsh: I have 2 questions. One is about the surgical application of nissen (fundoplication) during transplant. Are you doing that? What's the latest literature to help reduce aspiration?

Sweet: We are not doing fundoplications at the time of transplant. For lots of reasons, but primarily the data that everybody needs a fundoplication are not clear, and the additional time and complications that come with that are not justified by the benefits. The answer is that we're not doing that regularly. The data overall are still very murky as to whether patients benefit from that a priori as opposed to in response to knowledge that there's reflux.
Walsh: And then long-term, do you provide any airway clearance therapies because of their inability sometimes to recognize they need to cough? Is there any type of therapy that we should be recommending for these lung transplant patients?

Sweet: You ask a great question, and that question began to crystallize in my mind as I was looking at these data. The answer right now is that we are not. We tend to wait until we see lots of mucus accumulation in our screening bronchoscopies when we've got recurrent infections. We tend to be more symptom-driven and outcome-driven rather than prophylacticdriven. I think that's an important question that could be answered. If we took a more aggressive approach and if we recognized, as I showed you, that the patients are going to have impairment in their ability to recognize the need to cough, should we be more aggressive, and would that change the long-term outcome? I think that's a really important question.

Walsh: Especially the kids with $\mathrm{CF}$ who are used to doing it, can they continue to do those therapies?

Sweet: The reality is that most of those kids are going to be more sensitized to the accumulation of mucus even though they won't have the same sensation in their lungs; they have proximal sensation. Most of those kids are doing mucus clearance even if I don't tell them to specifically.

Stokes: You mentioned azithromycin, but how about inhaled steroids in lung transplant bronchiolitis obliterans?
Sweet: The data supporting the use of that are really thin; nobody has really focused on that. There was a study 3 that came out years ago, but it really hasn't caught on in any way, shape, or form. Unfortunately, the approach that's used in bronchiolitis obliterans after bone marrow transplant doesn't translate well to post-lung transplant. And I don't know why; I can't explain it. It may be that the underlying etiology is slightly different, but you would think it would be a common pathway.

Stokes: What do you think is the most sensitive indicator of development; do you use lung function?

Sweet: Yes. At this point that's your best mechanism. The challenge, of course, is in infants and younger children, where we don't do lung function and we're relying more (and I didn't spend time on this) on imaging studies, both high-resolution CT and ventilation perfusion scanning for evidence of air trapping. Those are the other indicators that we use. It's interesting that the literature is now catching up with us in the adult world of using techniques like high-resolution CT to pick up signs of bronchiolitis obliterans.

\section{REFERENCES}

1. Levvey BJ, Harkess M, Hopkins P, Chambers D, Merry C, Glanville AR, Snell GI. Excellent clinical outcomes from a national donation-after-determination-of-cardiacdeath lung transplant collaborative. Am J Transplant 2012;12(9):2406-2413.

2. Cypel M, Yeung JC, Liu M, Anraku M, Chen F, Karolak W, et al. Normothermic ex vivo lung perfusion in clinical lung transplantation. N Engl J Med 2011;364(15):1431-1440.

3. Speich R, Boehler A, Russi EW, Weder W. A case report of a double-blind, randomized trial of inhaled steroids in a patient with lung transplant bronchiolitis obliterans. Respiration 1997;64(5):375-380. 